\title{
scripted
}

Volume 13, Issue 1, May 2016

\section{Comparative Case Studies in Implementing Net Neutrality: A Critical Analysis of Zero Rating}

\author{
Christopher T. Marsden *
}

\begin{abstract}
This article critically examines the relatively few examples of regulatory implementation of network neutrality enforcement at national level. It draws on coregulatory and self-regulatory theories of implementation and capture, and interdisciplinary studies into the real-world effect of regulatory threats to traffic management practices (TMP). Most academic and policy literature on net neutrality regulation has focussed on legislative proposals and economic or technological principles, rather than specific examples of comparative national implementation. This is in part due to the relatively few case studies of effective implementation of legislation. The article presents the results of fieldwork in South America, North America and Europe over an extended period (2003-2015). The countries studied are: Brazil, India, Chile, Norway, Netherlands, Slovenia, Canada, United States, and those within the European Union. Empirical interviews were conducted in-field with regulators, government officials, ISPs, content providers, academic experts, NGOs and other stakeholders from Chile, Brazil, United States, India, Canada, United Kingdom, Netherlands, Slovenia, Norway. It also explores the opaque practices of co-regulatory forums where governments or regulators have decided on partial private rather than public diplomacy with ISPs, notably in the US, Norway and UK. The article notes the limited political and administrative commitment to effective regulation thus far, and draws on that critical analysis to propose reasons for failure to implement effective regulation. Finally, it compares results of implementations and proposes a framework for a regulatory toolkit. The specific issue considered are the tolerance of zero rating practices, notably as deployed by mobile ISPs.
\end{abstract}

DOI: $10.2966 /$ scrip.130116.1

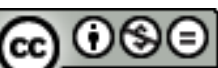

EY NC ND (C) Christopher T. Marsden 2016. This work is licensed under a Creative Commons Licence. Please click on the link to read the terms and conditions.

\footnotetext{
* Professor, University of Sussex School of Law, Sussex, United Kingdom.
} 


\section{Introduction}

This article critically examines the relatively few examples of regulatory implementation of network neutrality enforcement at national level, focussed on zero rating. It studies co-regulation (where legislation permits regulation but the regulator forbears given evidence of effective self-regulation) and self-regulation schemes' implementation and capture, ${ }^{1}$ and interdisciplinary studies into the real-world effect of regulatory threats to traffic management practices (TMP). Most academic and policy literature on net neutrality regulation has focussed on legislative proposals and economic or technological principles, rather than specific examples of comparative national implementation, which are of more recent vintage. I examine the relatively few case studies of effective implementation of legislation, and make comparisons with appropriate fieldwork to assess the true scope of institutional policy transfer.

This article presents the results of fieldwork in South America, North America and Europe over an extended period (2003-2015), the latter part of which focussed on implementation. It also examines the ground-breaking example of India, where a successful anti-Facebook campaign by civil society in 2015 resulted in regulation to ban zero rating announced on 8 February $2016 .^{2}$ The other countries studied are: Brazil, Chile, Norway, Netherlands, Slovenia, United States, and those within the European Union. This article is based on rigorous in-country fieldwork. ${ }^{3}$ Empirical interviews were conducted in-field with regulators, government officials, ISPs, content providers, academic experts, NGOs and other stakeholders from Chile, Brazil, United States, Canada, United Kingdom, Netherlands, Slovenia, Norway. (Note the UK is locked into a "light touch" regulatory regime, which has focussed on behavioural "nudge" responses to net neutrality violations, though it has also conducted technical measurement of both broadband speeds and traffic measurement, as well as a recent study into types of monitoring, so that "regulators keep a close watch on the operations of the market, using frequent detailed traffic measurement reports." ${ }^{4}$ The UK is not further considered in this article except as subject to European law.)

The article notes the limited political and administrative commitment to effective regulation thus far in the countries examined, and draws on that critical analysis to propose reasons for failure to implement effective regulation. Finally, it compares results of implementations and proposes a framework for a regulatory toolkit for those jurisdictions that intend effective practical implementation of some or all of the net

\footnotetext{
${ }^{1}$ See definitions in B Leveson, 'An Inquiry Into the Culture and Ethics of the Press, Politicians and Police: Volume IV' (2012) at 1739, Para 2.31 available at https://www.gov.uk/government/uploads/system/uploads/attachment_data/file/270943/0780_iv.pdf, (accessed 22 Mar 16).

2 "Prohibition of Discriminatory Tariffs for Data Services Regulations" (No.2 of 2016,2016) Gazette of India.

${ }^{3}$ With the exception of Chile, where the UN CEPAL in 2013 and Brazilian CGI in 2015 provided a forum for Chilean stakeholders to travel to workshops on comparative implementation.

4 J Crowcroft, "The UK Does not Yet Need Net Neutrality Regulations" (2015) available at http://phys.org/news/2015-03-uk-doesnt-net-neutrality.html (accessed 9 Feb 16).
} 
neutrality proposals currently debated. The specific issue considered is the tolerance of zero rating practices, notably as deployed by mobile ISPs.

\section{Case Studies in Net Neutrality Regulation}

Net neutrality has advanced from thwarted regulatory proposal to actual regulatory action in several advanced and developing nations since 2012. Prior to that, theorists lined up on either side of the debate, for and against specific regulation, in the United States and Europe. ${ }^{5}$ While regulatory and legislative logjams and litigation have resulted in delayed implementation of regulation in the United States, Brazil and European Union in the period since their respective initial intentions to regulate were announced in $2009,{ }^{6}$ several countries have passed legislation and/or implemented regulation of net neutrality. Table 1 below details the nation, legislation or regulation, its date of publication, and the date of enforcement, if any. The case studies detail those incidents of enforcement, for instance the 2014 actions in Netherlands and 2015 in Slovenia. It is assumed the Indian regulations will be enforced following the sixmonth grace period for existing zero rated packages.

\footnotetext{
${ }^{5}$ The two opposing law and economics camps on these issues in the origins of the debate are described in C Marsden et al, "Assessing Indirect Impacts of the EC Proposals for Video Regulation" (2006) available at http://stakeholders.ofcom.org.uk/binaries/research/tv-research/videoregulation.pdf (accessed 5 Mar 16). For those against regulation, see e.g. R Hahn and S Wallsten, "The Economics of Net Neutrality" (2006) available at https://server1.tepper.cmu.edu/ecommerce/Economics\%20of\%20Net\%20Neutrality.pdf (accessed 5 Mar 16); J Speta, "FCC Authority to Regulate the Internet: Creating It and Limiting It" (2004) 35 Loyola University Chicago Law Journal 15-39; C Yoo, "Network Neutrality and the Economics of Congestion" (2006) 94 Georgetown Law Journal 1847-1908. For those in favour of regulation, see e.g. M Lemley and L Lessig, Ex Parte Declaration Of Professor Mark A. Lemley And Professor Lawrence Lessig In The Matter Of: Application For Consent To The Transfer Of Control Of Licenses of MediaOne Group, Inc. To AT\&T Corp (1999) available at https://cyber.law.harvard.edu/works/lessig/cable/fcc/fcc.html (accessed 5 Mar 16); T Wu, "Network Neutrality, Broadband Discrimination" (2003) 2 Journal on Telecommunications and High Technology Law 141-172; T Wu, "When Code Isn't Law" (2003) 89 Virginia Law Review 679-751; T Wu, "Wireless Carterfone" (2007) 1 International Journal of Communication 389-426; R Frieden, "What Do Pizza Delivery and Information Services Have in Common? Lessons From Recent Judicial and Regulatory Struggles with Convergence" (2006) 32 Rutgers Computer and Technology Law Journal 247-296; B Cherry, "Misusing Network Neutrality to Eliminate Common Carriage Threatens Free Speech and the Postal System" (2006) 33 Northern Kentucky Law Review 483-511; N Economides and J Tåg, "Network Neutrality on the Internet: A Two-Sided Market Analysis" (2012) 24 Information Economics and Policy 91-104; P Weiser, "The Future of Internet Regulation" (2009) 43 UC Davis Law Review 529-590; B Frischmann and B van Schewick, "Yoo's Frame and What It Ignores: Network Neutrality and the Economics of an Information Superhighway" (2007) 47 Jurimetrics Journal 383428. Since that point, the debate has turned from theory to evidence and implementation details, on which this article focuses.
}

${ }^{6}$ C Marsden, "Summary of October Events Regulators" (2009) available at http://chrismarsden.blogspot.co.uk/2009/10/summary-of-october-events-regulators.html (accessed 9 Feb 16). 
Table 1. Notable net neutrality laws or regulation.

\begin{tabular}{|c|c|c|c|}
\hline Country & Legislation/regulation & Published & Date Enforced \\
\hline Norway & Guidelines $^{7}$ & $24 / 2 / 2009^{8}$ & $\begin{array}{l}\text { Zero rating declaration by } \\
\text { NKOM of } 2014\end{array}$ \\
\hline Costa Rica & $\begin{array}{l}\text { Sala Constitucional De La Corte } \\
\text { Suprema De Justicia }^{9}\end{array}$ & $13 / 7 / 2010$ & $\begin{array}{l}2010 \text { by Supreme Court } \\
\text { precedent }\end{array}$ \\
\hline Chile & Law $20.453^{10}$ & $18 / 8 / 2010$ & Decree $368,15 / 12 / 2010^{11}$ \\
\hline Netherlands & Telecoms Act $2012^{12}$ & $7 / 6 / 2012$ & $\begin{array}{l}2014 \text { and Guidelines } \\
15 / 5 / 2015^{13}\end{array}$ \\
\hline Slovenia & $\begin{array}{l}\text { Law on Electronic Communications } \\
2012^{14}\end{array}$ & $20 / 12 / 2012$ & Zero rating 2015 \\
\hline Finland & Information Society Code $(917 / 2014)^{15}$ & $17 / 9 / 2014$ & 2014 \\
\hline India & Regulations (No.2 of 2016) & $8 / 2 / 2016$ & $\begin{array}{l}\text { August: } 6 \text { months after } \\
\text { Gazette publication date }\end{array}$ \\
\hline Brazil & Law No. 12.965 & $23 / 4 / 2014$ & $\begin{array}{l}\text { Consultation 2015-16, no } \\
\text { implementation }^{16}\end{array}$ \\
\hline
\end{tabular}

7 See guidelines at Nkom, "Net Neutrality" (2014) available at http://eng.nkom.no/technical/internet/net-neutrality/net-neutrality (accessed 9 Feb 16).

${ }^{8}$ T Olsen, "Net Neutrality Activities at BEREC and Nkom, Norwegian Communications Authority" (2015), slide 5, available at http://berec.europa.eu/files/doc/2015-07-

13_09_56_36_3.\%20Noruega\%20Nkom\%20net\%20neutrality\%20-\%20Summit\%20BERECEaPeReg-REGULATEL-EMERG.pdf (accessed 9 Feb 16).

${ }^{9}$ Andrés Oviedo Guzmán, Fabio Isaac Masís Fallas Y Juan Manuel Campos Ávila, v. Ministerio De Ambiente, Energía Y Telecomunicaciones, Ministerio De La Presidencia (2010) Sala Constitucional de la Corte Supreme de Justicia available at http://www.technollama.co.uk/wpcontent/uploads/2012/04/Voto2010-12790SalaConstitucionalCR.pdf (accessed 9 Feb 16)

${ }^{10}$ See The Chilean "Law 20.453, which enshrines the principle of net neutrality for consumers and Internet users" (2010) available at http://www.leychile.cl/Navegar?idNorma=1016570\&buscar=NEUTRALIDAD+DE+RED (accessed 9 Feb 16).

${ }^{11}$ See http://www.subtel.gob.cl/images/stories/articles/subtel/asocfile/10d_0368.pdf (accessed 9 Feb 16).

12 See https://www.government.nl/documents/policy-notes/2012/06/07/dutch-telecommunications-act (accessed 9 Feb 16).

${ }^{13}$ Netherlands Department of Economic Affairs, Net Neutrality Guidelines May 15th, for the Authority for Consumers and Markets (ACM) for the enforcement by ACM of Article 7.4a of the Netherlands Telecommunications Act 2012 (2015).

14 “No. 003-02-10/2012-32” available at http://www.uradni-list.si/1/content?id=11144 (accessed 5 Mar 16).

${ }^{15}$ See https://www.finlex.fi/fi/laki/kaannokset/2014/en20140917 (accessed 9 Feb 16).

${ }^{16}$ For updates, see 'Ministry of Justice' (2016) available at http://pensando.mj.gov.br/marcocivil/ (accessed 9 Feb 16). 
I do not detail the United States and European Union in Table 1, as their regulation and legislation have been a drawn-out and complex series of actions summarised briefly in the case studies. Note that the European legislation is followed by guidelines to be issued by the body of regulators by end-August $2016 .{ }^{17}$ The United States regulator awaits a Federal Appeals Court decision on its 2015 regulation, ${ }^{18}$ during a Presidential electoral year. ${ }^{19}$ Neither the EU nor US is expected to prove active until late 2016. Both jurisdictions will produce a very substantial volume of regulatory analysis in coming years,${ }^{20}$ and this comparative treatment considers both only briefly.

Other well-known case studies include South Korea (2011-13), ${ }^{21}$ Japan (2009), ${ }^{22}$ Israel $(2011)^{23}$ and Singapore (2011). ${ }^{24}$ Much research has been conducted into net

\footnotetext{
${ }^{17}$ BoR 'Statement on BEREC's work to produce guidelines for the implementation of net neutrality provisions of the TSM regulation" (2015) available at http://berec.europa.eu/eng/document_register/subject_matter/berec/press_releases/5588-statement-onberec-work-to-produce-guidelines-for-the-implementation-of-net-neutrality-provisions-of-the-tsmregulation (accessed 22 Mar 16).
}

18 “Joint Mot. Stay or Expedition U.S. Telecom Ass'n, No. 15-1063" (2015) available at: https://www.publicknowledge.org/assets/uploads/blog/15.05.13_Motion_for_Stay.pdf (accessed 9 Feb 16); "Order No. 15-1063 Denying in Part \& Granting in Part Joint Mot. Stay or Expedition at 1-2, U.S. Telecom Ass'n, of June 11, 2015” https://www.publicknowledge.org/assets/uploads/blog/15.05.13_Motion_for_Stay.pdf (accssed 31 Mar 16); "DA 15-563 Protecting \& Promoting the Open Internet, Order Denying Stay Petitions, of May 8, 2015” https://apps.fcc.gov/edocs_public/attachmatch/DA-15-563A1.pdf (accessed 31 Mar 16).

${ }^{19}$ K Bode "ISPs Are Trampling Net Neutrality While The FCC Sits Boxed In By Lawsuits" (2016) available at: https://www.techdirt.com/articles/20160201/06351633480/isps-are-trampling-netneutrality-while-fcc-sits-boxed-lawsuits-upcoming-election.shtml (accessed 9 Feb 16).

${ }^{20}$ R Frieden, "Déjà vu All Over Again: Questions and a Few Suggestions on How the FCC Can Lawfully Regulate Internet Access” (2015) 67 Federal Communications Law Journal 325-376.

${ }^{21}$ D-H Shin, “A Comparative Analysis of Net Neutrality: Insights Gained by Juxtaposing the U.S. and Korea" (2014) 38 Telecommunications Policy 1117-1133, citing Korean Communications Commission, "Criteria on Reasonable Management and Use of Communications Networks and Transparency in Traffic Management” (2013).

${ }^{22}$ T Jitsuzumi, "Recent Development of Net Neutrality Conditions in Japan" (2015) available at http://www.slideshare.net/toshiyajitsuzumi/recent-development-of-net-neutrality-conditions-injapan?qid=aa9e9595-f430-434a-b6f2-1b2444237266\&v=default\&b=\&from_search=1 (accessed 9 Feb 16).

${ }^{23}$ A Cahan-Gonen, "Internet (over-the-top) Services and Challenges to Regulation" (2015) available at http://berec.europa.eu/files/doc/2.\%20Israel\%20adi\%20presentation\%20emerg\%2023.6.15\%20Israel.p df (accessed 9 Feb 16). See also E Greenbaum, "Net Neutrality II" (2014) available at https://israeltechnologylaw.wordpress.com/2014/02/13/net-neutrality-ii/ (accessed 9 Feb 16).

${ }^{24}$ Info-communications Development Authority of Singapore, "IDA's Decision and Explanatory Memorandum for the public consultation on Net Neutrality" (2011) available at https://www.ida.gov.sg/Policies-and-Regulations/Consultation-Papers-and-

Decisions/Store/Consultation-on-Policy-Framework-for-Net-Neutrality (accessed 5 Mar 16). Note that in such a censorious authoritarian state, the degree of openness of the consultation and its enforcement remain highly contentious. 
neutrality in other EU member states, notably the United Kingdom, ${ }^{25}$ Germany and France,${ }^{26}$ which has not been translated into specific net neutrality regulatory action. In Belgium, Italy and Luxembourg, proposals have been put forward for legislation, but no law has yet been passed, in view of the ongoing European Regulation negotiations since 2013. ${ }^{27}$ An exception to this regulatory activity is the United Kingdom, whose government opposes net neutrality, and whose regulator's role has been both restricted to encouraging self-regulation and since 2009 funding research by SamKnows into detection of TMP, and its effect on consumers. ${ }^{28}$ Empirical analysis of UK ISP practices show that net neutrality violations have been far more frequent in the UK than US. ${ }^{29}$

In each of the eight case studies, initial confusion at lack of clarity in net neutrality laws ${ }^{30}$ gave way to significant cases particularly since 2014 which have given regulators the opportunity to clarify their legislation or regulation. The majority of such cases relate to mobile (or in US parlance "wireless") net neutrality, and in particular so-called "zero rating" practices.

\subsection{Zero Rating}

The developed countries ${ }^{31}$ have recently legislated for or regulated for "net neutrality", the principle that Internet Service Providers (ISPs) should not discriminate between different applications, services and content accessed by their users. ${ }^{32}$ This victory for net neutrality proponents came after twenty years of attempted discrimination between content streams within the walled gardens of both fixed and mobile ISPs, such as AOL in the 1990s, and Vodafone Live/360 in 2002-11, which was intended to challenge the Apple AppStore and Android/GooglePlay. ${ }^{33}$ Alongside their walled gardens, these ISPs enforced monthly data caps preventing

\footnotetext{
${ }^{25}$ C Marsden, "Net Neutrality Regulation in the UK: More Transparency and Switching" (2014) available at http://papers.ssrn.com/sol3/papers.cfm?abstract_id=2423284 (accessed 9 Feb 16).

${ }^{26}$ C Jasserand, "Critical Views on the French Approach to "Net Neutrality"" (2013) 16 Journal of Internet Law 18-28.

${ }^{27}$ Based on the proposal for a law in COM(2013) 627 final 2013/0309 (COD) Proposal for a Regulation laying down measures concerning the European single market for electronic communications and to achieve a Connected Continent (2015) available at http://www.consilium.europa.eu/en/press/press-releases/2015/07/pdf/st10409-re01_en15_pdf/.
}

${ }^{28}$ It was proven by SamKnows in 2008 that British Telecom throttled all P2P traffic aggressively during evening peak. See B Collins, "Sam Shines a Light on BT's Traffic Shaping" (2008) available at http://www.alphr.com/news/internet/216252/sam-shines-a-light-on-bts-traffic-shaping (accessed 9 Feb 16).

${ }^{29}$ A Cooper and I Brown, "Net Neutrality: Discrimination, Competition, and Innovation in the UK and US” (2015) 15 ACM Transactions on Internet Technology 1-21.

30 C Marsden, "Presentation on Net Neutrality" (2013) available at http://chrismarsden.blogspot.co.uk/2013/10/presentation-on-net-neutrality-at.html (accessed 9 Feb 16).

${ }^{31}$ Commonly taken to encompass members of the Organisation for Economic Cooperation and Development (OECD): http://www.oecd.org (accessed 31 Mar 16).

${ }^{32}$ See Wu, "Network Neutrality, Broadband Discrimination" and "Wireless Carterfone", note 5 above.

${ }^{33}$ R Wray, "Vodafone 360: Mobile Provider Launches New Applications Service" (2009) available at http://www.theguardian.com/business/2009/sep/20/vodafonegroup-telecoms (accessed 5 Mar 16). 
their customers having unlimited use of the Internet. Fixed line walled gardens failed in view of the easy access to the open Internet at increasingly low cost offered by broadband access. A recent history is provided by Kantrowitz. ${ }^{34}$ Continued attempts to maintain walled gardens throughout the past decade have focussed on both "negative" and "positive" net neutrality. I explain both in turn.

Negative neutrality is the blocking and throttling of content that threatens the business model of the ISP. This can be relatively benign when it is spam email and viruses that are blocked. It can also be self-serving and anti-competitive when it is unjustified and unreasonable restrictions on users' preferred content that is affected - for instance peer-to-peer file sharing or video streaming. It is this "negative" net neutrality which is the target of most legislation in the area, based on the generic regulatory principle of "first, do no harm", in this case eliminating the harms caused by unreasonable negative blocking, or discrimination. Cases in the US such as Madison River and Comcast were about blocking, and it is this that rouses much consumer anger and political action. ${ }^{35}$

"Positive" net neutrality violations do not involve blocking, but treating some content better than general Internet traffic. As cable TV provides High Definition and standard video and television channels at high fees in a separate logical pathway to the general Internet traffic on its cable, some telecoms companies hope to partition its Internet traffic to replicate this business model. Several ISPs attempted this practice over lengthy periods, notably by excluding television channels from monthly data caps for users, positively discriminating in favour of their affiliated content and against other video providers (such as YouTube). In this way, "walled gardens" reappear with much more "Specialized Service" walls - restrictions that affect only certain non-affiliated types of Internet traffic, such as social networks or video. This exclusion of preferred content from data caps is described as "zero rating" because all that downloading costs precisely zero in terms of counting towards their monthly bill. ${ }^{36}$ Note that many fixed ISPs have virtually unlimited data use as part of their offer, made possible because maximum speeds and user profiles mean that the cumulative download burden does not over-strain the network.

Zero rating is only possible when users take an ISP subscription which has a data cap, which is generally a much lower limit imposed by mobile than fixed ISPs. Unlimited

34 A Kantrowitz, "How Facebook Stumbled On Its Quest to Give Internet Away For Free" (2016) available at http://www.buzzfeed.com/alexkantrowitz/how-facebooks-plan-to-give-the-world-freemobile-internet-we\#.hlW4oEnnR (accessed 9 Feb 16).

${ }^{35}$ C Marsden, "Net Neutrality Law: Past Policy, Present Proposals, Future Regulation? Proceedings of the United Nations Internet Governance Forum: Dynamic Coalition on Network Neutrality" (2013) available at http://ssrn.com/abstract=2335359 (accessed 9 Feb 16).

${ }^{36} \mathrm{C}$ Marsden, Network Neutrality: Towards a Co-regulatory Solution (London: Bloomsbury Academic, 2010), at 38-39, 96; A Odlyzko, B St Arnaud, E Stallman and M Weinberg "Know Your Limits Considering the Role of Data Caps and Usage Based Billing in Internet Access Service" (2012) available at https://www.publicknowledge.org/documents/know-your-limits-considering-the-role-ofdata-caps-and-usage-based-billing (accessed 9 Feb 16); P Maillé and B Tuffin, Telecommunication Network Economics: From Theory to Applications (Cambridge: CUP, 2014), at 89-90; J Eisenach, "Economics of Zero Rating" (2015) available at http://www.nera.com/content/dam/nera/publications/2015/EconomicsofZeroRating.pdf (accessed 9 Feb 16). 
data plans mean users can download as much data as needed using the open Internet pipe, whose speed is restricted only by the Internet itself, or the type of Content Delivery Network used to supply media. ${ }^{37}$ When a cap applies to a monthly subscription (such as 1 Gigabyte a month ${ }^{38}$ ), that limits the amount of content that a user will choose to access. If data is as expensive as it can be in developing countries, any content can prove too expensive to access for the average user. Offering certain content on a "zero rated" basis means that content will not be included in the monthly data capped allowance - which is particularly useful if that content is streamed video, audio or an application used regularly, such as social network Facebook or messaging app WhatsApp. That content may be locally stored, relieving congestion in the network, as a result of partnership with the ISP. This can justify in network engineering costs the decision to reduce the apparent end-user cost, if not to zero, then to a lower cost than other data.

A particular business model for this practice is that of dominant social network Facebook, which from 2009 introduced Facebook Zero with mobile ISP partners, and in 2015 introduced a wider walled garden called "Internet.org" (which despite its name is an Intranet for thirty-forty affiliates), which was rapidly renamed FreeBasics in late September 2015. ${ }^{39}$ The prize for FreeBasics was to grow subscribers in the Indian market more effectively: Zuckerberg stated:

[through] Internet.org in India now, there are already more than a million people who now have access to the internet who didn't otherwise [...] in terms of DAU (Daily Accessing User) growth, the three largest countries were India, the US and Brazil. ${ }^{40}$

In May 2015, opposition to the highly exclusive and non-transparent Internet.Org had led to content owners abandoning their previously negotiated tenancies, and mobile ISPs dropping the service. ${ }^{41}$ As India has more people in absolute poverty than all of Africa (and thus in need of subsidised Internet access), and a larger middle class who can afford to pay than all of Europe (the commercial argument for extending Facebook's reach as broadly into India as possible), Zuckerberg personally wooed the

\footnotetext{
${ }^{37}$ Explaining the use of ISP CDNs such as Sky and British Telecom, together with four commercial CDNs including Akamai, Atos, Level3 and Limelight see: BBC, "Information Policy \& Compliance Letter, "Freedom of Information Act 2000 - RF1201-40419, Information Compliance" (2014) available at http://downloads.bbc.co.uk/foi/classes/disclosure logs/digital and technology/RF1201-40419iplayer-content.pdf (accessed 9 Feb 16).

${ }^{38}$ The typical UK limit in 2015 was $2 \mathrm{~GB}$ /month. See "Mobile Internet: How Many Gigabytes Do You Need? Download Limits Explained" (2015) available at http://kenstechtips.com/index.php/what-does-

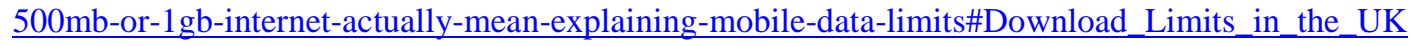
(accessed 5 Mar 16)

${ }^{39}$ G Helani, "Zero Rating: Are We in Danger of Killing the Goose Before Knowing If Its Eggs Are Golden?" (2015) available at http://blogs.cfr.org/cyber/2015/10/05/zero-rating-are-we-in-danger-ofkilling-the-goose-before-knowing-if-its-eggs-are-golden/ (accessed 9 Feb 16).

${ }^{40}$ Facebook, "Q3-2015 Earnings Call” (2015) available at http://investor.fb.com/results.cfm (accessed 9 Feb 16).

${ }^{41}$ C Marsden, "Zero Rating and Mobile Net Neutrality" in L Belli and P De Filippi (eds), Net Neutrality Compendium: Human Rights, Free Competition and the Future of the Internet (Cham, $\mathrm{CH}$ : Springer, 2016) 241-260.
} 
Indian Prime Minister for the relaunch, to mixed reviews. FreeBasics has less powerful gatekeeper functions than Internet.Org and more content is permitted, with officially only technical grounds for refusal, but it is still only governed by a contract with Facebook which it can unilaterally change.

Data caps have been controversial throughout the consumer Internet's history, especially in the United States where dial-up Internet was virtually free to the enduser (simply the cost of a local telephone call). The US Open Internet Advisory Committee in 2013 noted the move towards capping data especially for mobile users and worried "whether caps or thresholds that are set too low could lead to a world where the average user carefully monitors her bandwidth use" given uncertainty over data caps as a "transitory or permanent concern" which appears to be the case in developing (and many developed) nations' mobile data access. ${ }^{42}$ While data caps apply in many nations, applied by many ISPs, the user often has little or no idea that they are approaching their monthly limit until informed by the ISP, and such warnings are often inaccurate. It is at best a blunt weapon for handling congestion, though there is little argument that data caps per se do not infringe net neutrality, as long as the cap gradually increases over time. The OECD states "zero rating can clearly be procompetitive [...] becomes less of an issue with [...] higher or unlimited data allowances. Regulators need to be vigilant."43

Politicians and telecoms executives who now claim to be in favour of net neutrality are in fact conceding that blocking and throttling users is no longer acceptable to politicians and therefore regulators. They largely only concede "negative" net neutrality. "Positive" net neutrality is a much more contested topic, and where download limits apply or ill-defined "Specialized Services" carry the zero-rated content, this concept of zero rating will be heavily contested. That is more the case with mobile than fixed networks, and also with developing nations' mobile ISPs than developed.

\section{Case Studies}

The description thus far has relied to a large extent on the experiences of developed nations. Below I focus on nine case studies, including the earliest effective regulation in Norway, and the most recent regulation in its current form - the United States whose Open Internet Order became effective on 12 June 2015. I also discuss the European Union legislation and its proposed implementation.

Research into comparative net neutrality law has recently been carried out by several Non-Governmental Organisations (NGOs) and is well reported in the specialist media. ${ }^{44}$ Odlyzko et al noted that the zero-rating debate exists in one Asian country,

\footnotetext{
${ }^{42}$ Open Internet Advisory Committee, "Policy Issues in Data Caps and Usage-Based Pricing" (2013) at 13 available at https://transition.fcc.gov/cgb/oiac/Economic-Impacts.pdf (accessed 9 Feb 16).

${ }^{43}$ OECD, "OECD Digital Economy Outlook 2015: Main Trends in Communication Policy and Regulation" (2015) available at http://www.keepeek.com/Digital-Asset-Management/oecd/scienceand-technology/oecd-digital-economy-outlook-2015/main-trends-in-communication-policy-andregulation_9789264232440-6-en\#page22 (accessed 9 Feb 16).

${ }^{44}$ C Rossini and T Moore, "Exploring Zero-Rating Challenges: Views from Five Countries" (2015) available at https://www.publicknowledge.org/documents/exploring-zero-rating-challenges-views-
} 
but does not explore in depth, while I previously discussed monthly caps before zero rating had become commonly identified. ${ }^{45}$ Just as net neutrality dates to the 1990 s, and zero rating dates to the same decade even if the term of art was coined much later. ${ }^{46}$ There are ten times more mobile (5.6 billion) than fixed line connections $(572 \mathrm{~m})$ in developing countries, whereas the developed world ratio is $3: 1$. There are five times more mobile broadband subscriptions in the developing world with 2.37 billion to only 429 million fixed subscriptions (developed world 1.09billion mobile to $365 \mathrm{~m}$ fixed at a ratio of 3:1). Seventy percent of Internet users totalling over 2 billion people are outside the EU/US.

This article summarises each nation's development of net neutrality, and focuses on its implementation of regulation against zero rating since $2014 .{ }^{47}$ The methodology was based on both literature review and empirical interviews.

\subsection{Norway}

Norway has put in place co-regulation for net neutrality. ${ }^{48}$ The need for net neutrality resulted from an ISP choosing not to carry the video traffic of the state broadcaster, resulting in strong political pressure for neutrality. ${ }^{49}$ Sorensen, for the regulator, explains that he:

has worked together with the different stakeholders developing a model for net neutrality. In 2009 the Norwegian guidelines for net neutrality were launched and there have since been annual stakeholder meetings to monitor the status of net neutrality in Norway. ${ }^{50}$

from-five-countries (accessed 9 Feb 16). See also C Marques et al, "Internet: seis meses depois, em que pé que estamos?" (2015) available at http://artigo19.org/blog/analise-marco-civil-da-internet-seismeses-depois-em-que-pe-que-estamos/ (accessed 9 Feb 16). Additionally, many regulatory documents are available in Spanish, Portuguese and English on regulator websites. The consultation process for net neutrality regulation was very well publicised in Brazil, while Chile's 2010 law was well noted but little researched in academia outside Latin America.

${ }^{45}$ B St Arnaud, E Stallman and M Weinberg, see note 36 above; C Marsden, see note 36 above, citing Fierce Wireless, "Do Usage-Based Pricing Models Work?" (2011) available at http://www.fiercewireless.com/offer/pricing_models (accessed 9 Feb 16).

${ }^{46}$ M Lemley and L Lessig, see note 5 above; C Marsden, "Pluralism In The Multi-Channel Market: Suggestions For Regulatory Scrutiny Council of Europe Human Rights Commission” (1999) Mass Media Directorate, MM-S-PL [99] 12 Def 2.

${ }^{47}$ A longer treatment will be provided in C Marsden, Network Neutrality (Manchester: Manchester University Press, forthcoming).

${ }^{48}$ In addition to semi-regular (annual) meetings with the regulator in Oslo, Dublin, Edinburgh, Brussels and Barcelona, I am grateful to representatives of the Norwegian consumer council, Opera software and Telenor for their comments. In Oslo, I thank in particular Prof. Lee Bygrave of the University of Oslo for hosting the various meeting of the iGov and iGov2 projects to which he invited me to meet regulators and ministry officials.

${ }^{49}$ D Read, "Net Neutrality and the EU Electronic Communications Regulatory Framework" (2012) 20 International Journal of Law and Information Technology 48-72.

$50 \mathrm{~T}$ Olsen, "Net Neutrality Activities at BEREC and Nkom" (2015), at slide 5, available at http://berec.europa.eu/files/doc/2015-07- 
Sorensen states that "market players that have not formally endorsed the guidelines follow the guidelines in practice." Sorensen further explains that:

CDN servers that are connected to dedicated transmission lines or that use a higher priority level than "best effort" will not be considered net neutral... IPTV is provided on a closed network (i.e. not over the Internet) which can, in principle, be considered a modern form of cable TV. These types of services are often referred to as "specialised services" and as long as these are not provided at the expense of the Internet service, net neutrality will not apply for them. ${ }^{51}$

Note that in 2013, a new Norwegian electronic commerce law formally established that the guidelines must be followed by ISPs, ensuring that no confusion over 'selfregulation' arises. Neutrality was defined as excluding zero rating in 2014, in order to ensure ISPs did not attempt to introduce such a practice:

zero-rating lead to selected traffic from the Internet service provider itself or affiliated providers being favoured above other traffic. And this is exactly the kind of situation net neutrality aims to avoid. ${ }^{52}$

Sorensen of NKOM is co-chair of the BEREC (Body of European Regulators of Electronic Communications, established in 2009) ${ }^{53}$ Expert Working Group on Net Neutrality, and his comments on the recent EU/US regulations of 2015 are worthy of serious study:

US rules say that these services use some form of network management to isolate the capacity used by these services from that used by broadband Internet access services. Regarding the latter, the European rules say that sufficient capacity shall be available so that the availability and quality of internet access services for other end-users are not impaired in a material manner, a wording actually allowing degradation of the quality of the Internet access service! $!^{54}$

Norway is unique in that its co-regulatory net neutrality approach was agreed prior to other European nations, yet remains in place unchallenged by affected companies (the largest ISP Telenor does actively zero rate in Asian nations where it has affiliates). Note that Norway practices an advanced form of Scandinavian social democracy, supported by strong and independent bureaucracy and government, a social compact

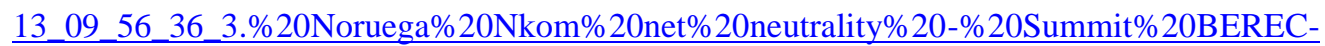
EaPeReg-REGULATEL-EMERG.pdf (accessed 9 Feb 16).

51 F Sorensen, "The Norwegian Model for Net Neutrality" (2013) available at http://eng.nkom.no/topical-issues/news/the-norwegian-model-for-net-neutrality (accessed 9 Feb 16).

${ }^{52}$ F Sorensen, "Net Neutrality and Charging Models" (2014) available at http://eng.nkom.no/topicalissues/news/net-neutrality-and-charging-models (accessed 9 Feb 16).

${ }^{53}$ Regulation (EC) No 1211/2009 of 25 November 2009 establishing the Body of European Regulators for Electronic Communications (BEREC) and the Office, OJ L 337, 18.12.2009, at 1.

${ }^{54}$ F Sorensen, "A Comparison between European and US Approaches to Net Neutrality" (2015) available at http://eng.nkom.no/topical-issues/news/a-comparison-between-european-and-usapproaches-to-net-neutrality (accessed 9 Feb 16) (emphasis added). 
between companies and society, and economic growth fuelled by North Sea oil wealth. It may therefore prove an exception to the general rule of litigious companies, who plead poverty in the current low growth period for developed economies, and captured regulators responding to those conditions and a lack of either commitment to or expertise in analysing net neutrality. Telenor, the former national monopoly, did criticise the self-regulatory rules in $2011,{ }^{55}$ but continued to comply with the increased scrutiny in the move to co-regulation in 2013. The Norwegian Consumer Council is a vigorous civil society proponent of net neutrality. ${ }^{56}$ Norway is by no means typical, and as the earliest effective regulator is an outlier.

\subsection{Netherlands}

The Netherlands in mid-June 2011 moved to implement the powers to require Quality of Service guarantees without discrimination, in response to consumer outcry at ISP use of intrusive monitoring in order to block the messaging service WhatsApp, but its formal legislation and then regulatory implementation took a further three years. ${ }^{57}$ Netherlands network neutrality regulation was voted on by its Senate on 6 March $2012,{ }^{58}$ which made it the first European nation to formally introduce mandated network neutrality. The 2012 law prohibits traffic management that discriminates, with few exceptions. In Netherlands, these are:

[a] to minimize the effects of congestion, whereby equal types of traffic should be treated equally; [b] to preserve the integrity and security of the network and service of the provider in question or the terminal of the end-user; plus to stop spam and enforce legal requirements. ${ }^{59}$

Implementation of the law was delayed until spring 2013 by the need for secondary legislation from the Ministry mandating the regulator to implement the law, and the regulator was merged into the competition authority in April 2013, further delaying

\footnotetext{
${ }^{55} \mathrm{~N}$ Anderson, “Cash, Please! A Norwegian Change of Heart on Net Neutrality” (2011) available at http://arstechnica.com/tech-policy/2011/01/a-nordic-change-of-heart-on-net-neutrality/ (accessed 9 Feb 16).

${ }^{56} \mathrm{~T}$ Nortvedt, "Statement by The Norwegian Consumer Council to The European Commission's Online Public Consultation on 'Specific Aspects of Transparency, Traffic Management and Switching in an Open Internet"” (2012) available at http://ec.europa.eu/newsroom/dae/document.cfm?doc id=3057 (accessed 5 Mar 16).

57 Bits of Freedom, "Non-official Translation of the Provision In Article 7.4a of the Telecommunications Act and its underlying considerations" (2015) available at https://www.bof.nl/2011/06/15/net-neutrality-in-the-netherlands-state-of-play (accessed 9 Feb 16).

${ }^{58}$ Netherlands Telecommunications Act 2012, art 7.4a(3), translated by the Dutch government, available at https://www.government.nl/binaries/government/documents/policynotes/2012/06/07/dutch-telecommunications-act/telecommunications-act.pdf (not official legal translation) (accessed 5 Mar 16).

${ }^{59}$ Netherlands' regulators were not required to implement net neutrality until summer 2013, a deadline delayed by the need for the Ministry to issue secondary legislation and guidance to the regulator on the form that such implementation should take. It is therefore too soon to draw firm conclusions about the efficacy of the Netherlands' law.
} 
implementation. ${ }^{60}$ By late 2014 it was issuing regulatory decisions to enforce net neutrality and prevent discrimination. ${ }^{61}$ The practice of zero rating has been outlawed by Netherlands in 2015 Guidelines clarifying application of its 2012 net neutrality law. ${ }^{64}$ Field research reveals the effectiveness of such laws and their operator and consumer effects. ${ }^{62}$ The new Netherlands rules only affect mobile ISPs in practice, as van Eijk explains: "The new neutrality rules had no effect on the fixed market." ${ }^{63}$ The issues dealt with by the Netherlands regulator once its net neutrality law came into effect caused van Eijk to caution that "hard cases make bad laws":

[T] he new net neutrality rules...led to a new subscription structure, with a substantially increased emphasis on data traffic. Data bundles are priced more specifically, and existing packages with unlimited data access have been replaced by packages with a specific size (data caps) and specific speeds.

He cautions that "it is too early to tell whether net neutrality has had an effect on the overall costs for mobile broadband." He explains: "In two cases, the Authority investigated the bundling of data packages with free services (i.e. a mobile subscription with 'free' access to Spotify). To deal with these cases, a new guideline has been drafted by the ministry involved." ${ }^{\prime 4}$ This clarifies that zero rating is illegal in the Netherlands, though it may not be a ruling that is compatible with the new draft European law which may be implemented in 2016. The decisions made in January 2015 have been severely criticised but remain the regulatory standard at the time of writing. ${ }^{65}$ I discuss this further in the European Union case study.

\footnotetext{
${ }^{60}$ From 1 April 2013, OPTA (Onafhankelijke Post en Telecommunicatie Autoriteit, Independent Post and Telecommunications Authority) merged with the Competition and Consumer Authorities into the ACM (Autoriteit Consument en Markten, Authority for Consumers \& Markets). In the Netherlands, I conducted interviews in 2012-2015 with Robert Stil and Mark de Hek of ACM, Professor Nico van Eijk, Mariejte Schaake MEP, and had many conversations with researchers at IVIR, Amsterdam, Bits of Freedom, and Oxford researcher Ben Zevenbergen. My former co-blogger Dr Jasper Sluijs was also a source of informed comment.
}

${ }^{61}$ M Peitz and F Schuett, "Net Neutrality and Inflation of Traffic TILEC Discussion Paper No. 2015 006" (2015) available at http://ssrn.com/abstract=2573466 (accessed 5 Mar 16).

${ }^{62}$ I conducted personal interviews with the relevant national experts in April 2013 (the Netherlands) and June 2013 (Slovenia), as well as the Minister responsible in Slovenia (August 2013) and consumer representatives (June 2013). More such research with operators and consumer groups is needed.

${ }^{63} \mathrm{~N}$ van Eijk, "The Proof of the Pudding is in the Eating: Net Neutrality in Practice" (2014) available at http://papers.ssrn.com/sol3/papers.cfm?abstract_id=2417933 (accessed 5 Mar 16).

${ }^{64}$ The other two cases in 2013/14 concerned public Wi-Fi and mobile ISP throttling. See N van Eijk, note 63 above, at 6: "The regulator in charge - the Authority for Consumers and Markets - took a first decision on applying the new rules in a case where Internet access in trains was blocked for congestion reasons. In another case, a service similar to WhatsApp was inaccessible via wireless networks."

${ }^{65}$ TeleGeography, “ACM Fines KPN, Vodafone for Net Neutrality Violations” (2015) available at https://www.telegeography.com/products/commsupdate/articles/2015/01/27/acm-fines-kpn-vodafonefor-net-neutrality-violations/ (accessed 9 Feb 16). 


\subsection{Slovenia}

Due to the language, limited regulator and the peripheral nature of Slovenian (population 2 million), Slovenia's very strict net neutrality law has been analysed very little by non-Slovenes. The net neutrality law is Article 203 of the wider Electronic Communications Law 2012 (ZEKOM), drafted as an innovation measure in response to hostility by the dominant ISP and trades unions towards competition in Internet supply. The regulator is the Communications Networks and Services Agency of the Republic of Slovenia (AKOS). The law's author when Minister for Communications, Professor Ziga Turk, has examined its genesis and implementation in a publication for the European Commission. ${ }^{66}$ His main conclusion was that implementing net neutrality in a nation with such a weak regulator would prove very difficult. Drossos agreed with this analysis arguing that AKOS "led by a former industry executive, has not been an advocate of net neutrality. Instead, it has taken a pro-industry stance on net neutrality and has not opposed attempts to weaken or even remove net neutrality provisions from the law." 67

While the ZEKOM law dates to the start of 2013, its regulation by AKOS was slow to arrive, with the main four rulings those of 24 January and 20 February 2015 against zero rating. AKOS confounded its critics with a strong zero rating decision when forced to investigate by the Electronic Communications Council (SEK), which filed a complaint in July 2014 alleging Telekom Slovenije violated net neutrality with zerorated products. Telekom Slovenije from 2013 provided free data for video channel HBO and UEFA Champions League football, then later the music streaming service Deezer. AKOS also found against Si.mobil (the largest mobile ISP) for zero-rating cloud storage service Hanger Mapa. TS and Si.mobil were instructed to stop zero rating. In the second pair, bans were imposed against a zero-rated mobile TV service and web portal provided by AMIS (Mobia TV) and Tušmobil (Tuškamra), respectively. That completes rulings against all major ISPs in Slovenia, all of whom had zero rated affiliated content, and were given sixty days to comply. The issue was fought for by AKOS against substantial industry lobbying and the huge asymmetry in personnel between the ISPs and the very small regulator.

A remaining issue is that football and cloud storage on Telecom Slovenije remains zero rated, though it stopped the practice with HBO, whereas AMIS and Si.mobil were banned from video and cloud zero rating. The importance of Champions League football to many users meant it may be politically impossible to deprive viewers of that stream by capping downloads in Slovenia. The results of bans have been "Telekom Slovenije and Si.mobile have both come up with special offers and packages with larger data caps or inexpensive data cap options" ${ }^{8}$ to expand the cap,

${ }^{66}$ Z Turk, "Net Neutrality Legislation - The Case of Slovenia" in C Marsden et al, "Deliverable 4.3: Final Report" Internet Science EINS Project FP7-288021 (2015) available at http://www.internetscience.eu/publication/1149 (accessed 9 Feb 16), Annex 23-31. I declare an interest as co-author.

${ }^{67}$ D Caf, "Zero-Rating Violates Slovenian Net Neutrality Law, Competitive Analysis \& Foresight: Policy, Regulation and Strategy in Network Industries" (2014) available at http://blog.caf.si/2014/12/zero-rating-violates-slovenian-net-neutrality-law.html (accessed 9 Feb 16).

${ }^{68}$ D Caf, "Another Win for Net Neutrality Advocates in Slovenia: AKOS Issues New Decisions Limiting Zero-Rating, Competitive Analysis \& Foresight: Policy, Regulation and Strategy in Network 
presumably to try to include their formerly zero-rated services. Just as in the US, Slovenian operators and the regulator are highly litigious and a final judicial decision was awaited in all cases.

\subsection{Chile}

Chile has the earliest known net neutrality law (from 18 August 2010) ${ }^{69}$ and an implementation of regulation permitting zero rating from 2014. Ley 20.453 includes a provision which adds Article $24(\mathrm{~h}-\mathrm{j})$ to Ley $\mathrm{N}^{\circ} 18.168$ "General de Telecomunicaciones." Article $24 \mathrm{H}$ expressly forbids ISP practices that "arbitrarily distinguish content, applications or services based on the source or ownership thereof." This would be relied upon by those opposed to zero rating. The original law required ISPs to self-report on any violations, resulting in infringement only for failure to report. Cerda reports that there were "allegations of negligent supervision of the law by public authority" in failing to enforce consumer rights. ${ }^{70}$

In Chile, ${ }^{71}$ all four mobile ISPs (Claro, Entel, Telefonica and VTR) were notified to cease zero rating in $2014 .{ }^{72}$ The regulator's (sub-secretary of communications: SubTel) conclusion was misreported in the developed nations' media as banning all zero rating from 1 June 2014, when it applied to social networks, notably Facebook and therefore Internet.Org.

SubTel stated: "las empresas que entregan algunas redes sociales gratis, lo que hacen es privilegiar el uso de estos servicios, mediante el acceso a una Internet bloqueada, excluyendo las redes sociales privilegiadas" - social networking apps received positive discrimination ("privilegiadas") when included in the zero rated offer. The Chilean situation is complicated by Wikipedia Zero announcing on 22 September 2014 it negotiated an exemption from the rules, on the basis that it is neither a social network nor a commercial offer. ${ }^{73}$ As carriers have not asked SubTel to confirm this exemption, and Wikimedia does not have standing (as a non-carrier) to request that

Industries" (2015) available at http://blog.caf.si/2015/02/another-win-for-net-neutrality-advocates-inslovenia-akos-issues-new-decisions-limiting-zero-rating.html (accessed 9 Feb 16).

${ }^{69}$ The Chilean "Law 20.453, which enshrines the principle of net neutrality for consumers and Internet users" (2010) available at http://www.leychile.cl/Navegar?idNorma=1016570\&buscar=NEUTRALIDAD+DE+RED (accessed 9 Feb 16). Law 20.453 is implemented by Decree 368 of 15 December 2010, available at http://www.subtel.gob.cl/images/stories/articles/subtel/asocfile/10d_0368.pdf (accessed 9 Feb 16).

70 A Cerda, "An Evaluation of the Net Neutrality Law in Chile" (2013) available at http://www.digitalrightslac.net/en/una-evaluacion-de-la-ley-de-neutralidad-de-la-red-en-chile/ (accessed 9 Feb 16).

${ }^{71}$ H Roa and P Mariano, "La Neutralidad de la Red: El Caso Chileno" (2015) at 20 available at http://berec.europa.eu/files/doc/2015-07-

13_10_00_01_4.\%20Neutralidad\%20de\%20la\%20red\%20versi+|n\%20final.\%20(3).pdf (accessed 9 Feb 16).

${ }^{72}$ In Chile, a total of forty cases may sound substantial, but twenty-five were in the first two years, and fully twenty-nine relate to those four major ISPs. Most were for infringement of transparency rules or network self-measurement. Zero rating in 2014 was considered by many observers as the first true test.

${ }^{73}$ Y Welinder and C Schloeder, "Chilean Regulator Welcomes Wikipedia Zero" (2014) available at http://blog.wikimedia.org/2014/09/22/chilean-regulator-welcomes-wikipedia-zero/ (accessed 9 Feb 16). 
official explanation, the evidence for this is Wikimedia's version of the exchange and its continued zero rated offer in Chile.

In fact, Claro (subsidiary of Mexican operator America Movil, also active in Brazil, Columbia and other Latin American nations) was permitted by the Chilean regulator to continue zero rating as long as it formed part of a wider data plan that customers could choose. ${ }^{74}$ This was because data plans were included in the new zero rating offer, removing the part of the complaint relating to "cuando los usuarios salen a través de un enlace externo, las empresas piden pagar" - that non-zero rated websites have to pay for users to exit zero rating onto the wider Internet. Zero rating would have to stop when users exhausted their data plan each month, so that they were not left with only zero rated content which would be very explicit discrimination.

\subsection{Brazil}

Brazil has had zero rating since prior to 2014 , a common practice by several mobile ISPs. Like Chile, Brazil has a bicameral constitution with a powerful directly elected executive president. Brazil had discussed net neutrality since the mid-2000s, with its formal advisory committee on Internet governance passing a resolution known as the "Decalogue" in 2009 which in part stated: "Filtering or traffic privileges must meet ethical and technical criteria only, excluding any political, commercial, religious and cultural factors or any other form of discrimination or preferential treatment." 75 This led to a period of public consultation led by the Ministry of Justice in 2009 (29 October-17 December) over a potential new legal framework. In 2011, the Chamber of Deputies (lower house of parliament) began to negotiate a law on privacy and net neutrality led by Deputy Alessandro Molon, which stalled in 2012/13.

In late 2013, the political process was accelerated due to President Roussef's concerns over foreign surveillance of telecoms and Internet traffic (specifically her own communications), resulting in the Senate ratifying the Chamber of Deputies' proposed law in a single month. ${ }^{76}$ Law No.12/965 (the "Marco Civil da Internet") was signed by the President at the opening ceremony of the Net Mundial conference in Sao Paolo in April 2014. ${ }^{77}$ The relevant section is Article 9 which states: "The party responsible for the transmission, switching or routing has the duty to process, on an isonomic [equality before the law] basis, any data packages, regardless of content, origin and destination, service, terminal or application." According to Article 9(3) ISPs must "act with proportionality, transparency and isonomy" and "offer services in non-

\footnotetext{
74 The draft Direction of May 2014 apparently banned all zero rating, but the final decision of August 2014 permitted those plans offered only in addition to a data plan - i.e. where users had purchased wider access to escape the walled garden.

75 "Resolução 2009/03 do CGI.br" (2009) available at http://www.cgi.br/resolucoes/documento/2009/003 (accessed 5 Mar 16).

${ }^{76}$ M Wohlers, M Giansante, A Carlos and N Fodich, "Shedding Light on Net Neutrality: Towards Possible Solutions for the Brazilian Case" (2014) Conference Paper presented to International Telecommunications 20th Cociety available at https://www.researchgate.net/publication/274310761_Shedding light_on net_neutrality towards_poss ible solutions for the Brazilian_case (accessed 5 Mar 16).

${ }^{77}$ Law No. 12.965, April 232014 by the Presidency of the Republic, Civil House Legal Affairs Subsection.
} 
discriminatory commercial conditions and refrain from anti-competition practices." The question for regulators implementing zero rating is whether it is proportional, transparent and non-discriminatory.

Unsurprisingly for such a rushed final law, the consequent implementation has proved controversial, not least because it is not clear which of two consultative bodies and the Ministry of Justice should be in charge of the drafting and enforcement of the subsequent rules. ${ }^{78}$ Article 9(1) states that it: "shall be regulated in accordance with the private attributions granted to the President... upon consultation with the Internet Steering Committee [CGI] and the National Telecommunications Agency [Anatel]". In 2015, both the regulator and the Ministry issued consultations, the latter organised together with the CGI in the period 28 January-30 April. ${ }^{79}$ The results of the consultation are to be made public in an Presidential Decree expected in 2016.

It is unclear whether zero rating or Specialized Services will be effectively regulated at the time of writing. At the 2015 Summit of the Americas in Panama on 10th April, President Rousseff met Mark Zuckerberg and was photographed with him, ${ }^{80}$ he in a suit, she in a Facebook hoodie. ${ }^{81}$ Her pronouncements in favour of Facebook's work in Brazil with poorer communities, and by inference Internet.Org, were a public scandal in view of the open consultations then ongoing. However, it is not clear what benefit such public lobbying achieved for Facebook/Internet.Org/Free Basics.

In practice, Anatel in 2014 chose not to regulate zero rating. TIM (the Brazilian subsidiary of Telecom Italia Mobile), in partnership with WhatsApp, released a zero rating plan that allowed subscribers to use the app in zero rating. Marcelo Bechara, counselor of Anatel, refused to regulate in the absence of specific prohibitions: "If there is no prioritized traffic, I do not see why it breaks the Marco Civil. This is the free market. It's free business." 82

In 2015, Claro abandoned a previous offer that offered zero rating only, and adopted its Chilean approach with free WhatsApp, Facebook and Twitter offered only to users

\footnotetext{
${ }^{78}$ F Cruz, J Marchezan and M dos Santos, "What is at Stake in the Regulation of the Marco Civil Da Internet?" (2015) available at http://www.internetlab.org.br/en/news/what-is-at-stake-in-the-regulationof-the-marco-civil/ (accessed 5 Mar 16).

${ }^{79}$ Ministerio da Justicia, "Civil Rights Framework for the Internet in Brazil: Information in English About the Consultation" (2015) available at http://pensando.mj.gov.br/marcocivil/civil-rightsframework-for-the-internet-in-brazil/ (accessed 9 Feb 16) and M Chilvarquer, "Debate Público Regulamentação do Marco Civil da Internet, Secretaria de Legislativos Assuntos, Ministeria da Justicia, paper presented at Conferência Internacional sobre a Elaboração de Regras de Neutralidade de Rede," (2015) available at: http://direitorio.fgv.br/eventos/Conferencia-Internacional-sobre-aElaboracao-de-Regras-de-Neutralidade-de-Rede (accessed 9 Feb 16).

80 Brazilian Government, "Image of President with Facebook" (2015) available at http://www2.planalto.gov.br/centrais-de-conteudos/imagens/encontro-com-presidente-do-facebook (accessed 9 Feb 16).

${ }^{81}$ A Antunes, "Mark Zuckerberg Meets with Brazil's President at the 7th Summit of the Americas in Panama" (2015) available at http://www.forbes.com/sites/andersonantunes/2015/04/11/markzuckerberg-meets-with-brazils-president-at-the-7th-summit-of-the-americas-in-panama/ (accessed 9 Feb 16).

${ }^{82} \mathrm{C}$ Marques et al, note 44 above, at 66-67.
} 
who also subscribed to data plans (pre or post-pay). ${ }^{83}$ Claro CEO Carlos Zenteno had said in April that zero-rating plans were no longer part of the carrier's strategy as less than $1 \%$ of customers used only Facebook or Twitter, and in June added: "It's an evolution. We realized that it has no purpose only to offer zero-rating access to one site." Claro argues that zero-rating on top of existing data plans represents a positive discrimination that the consumer chooses. Anatel's decision on this issue will be critical to the future of Brazilian zero rating.

Ramos states that:

the gap between those who can pay for data caps and those who cannot afford them could lead to a two-tier internet: the 'internet of the rich', or those who are wealthy enough to pay for the unlimited access; and the 'internet of the poor', which would give access only to a few applications that would be affordable to poor people. ${ }^{84}$

In Brazil, such a digital divide has a potent political force, given that the policy of progressive governments since Cardoso was elected in 1994 has been to narrow the inequalities that grew in the military dictatorship and before. Brazil was becoming a less unequal society until its recent recession but as Ramos explains:

the existence of two different 'internets' could distance the rich from the poor (with application providers creating services aimed for the rich and 'light versions' aimed for the poor). Ultimately, it could lead to a replica of the social apartheid currently perceived in many developing countries, where slums have limited access. ${ }^{85}$

It could lead to a perceived "gringo net" where only the rich can afford to access the full Internet with its many foreign apps and services. That said, the ISPs plead in Brazil not to be made tools of social engineering, arguing that inequality is a matter for governments not companies, however integral their service to the socio-economic landscape.

Brazil has consulted on net neutrality in two phases, the first running in spring 2015 in which the zero rating issue emerged as the most significant and commented-upon controversy, the second from 27 January 2016. The second phase is not expected to result in the Ministry of Justice issuing new Regulations via Presidential Decree until at least late $2016,{ }^{86}$ and the eventual fate of zero rating is thus very uncertain. It remains legal in the absence of Anatel action unless that Decree results in a prohibition.

83 R Prescott, "Claro Brazil Resumes Zero-Rating Plans" (2015) available at http://www.rcrwireless.com/20150618/americas/latam-claro-brazil-resumes-zero-rating-plans (accessed 9 Feb 16).

${ }^{84}$ P Ramos, "Towards a Developmental Framework for Net Neutrality: The Rise of Sponsored Data Plans in Developing Countries" (2014) available at http://ssrn.com/abstract=2418307 (accessed 9 Feb 16).

${ }^{85}$ Ibid.

${ }^{86}$ Facebook message interview with Analysts Dr Luca Belli and Dr Eduardo Magrani at FGV-Rio Centre for Technological Studies, 2 February 2016. 


\subsection{India}

India has a population of 1.25 billion, with a billion mobile users or almost $80 \%$ of all citizens, but low data use on smartphones, and only 26 million fixed telephone connections. ${ }^{87}$ Only $57 \%$ of Indian (and $43 \%$ of Brazilian) smartphone users actually use data plans at all, and the average amongst those Indians who do was $80 \mathrm{MB}$ a month in 2015 (3-5\% of developed nation average usage) ${ }^{88}$ With a very low fixed Internet subscription rate, most Indian consumers primarily rely on the mobile Internet for data.

The regulator is the Telecom Regulatory Authority of India (TRAI), which had consulted on net neutrality in 2006 when the issue first arose, with little public debate ${ }^{89}$ By contrast its spring 2015 consultation produced over a million emails in reply, focussed on zero rating. ${ }^{90}$

In India, three zero-rated options were offered in 2015, by both Internet.Org, owned by Facebook using the Reliance network, and Airtel (the largest mobile IAP in India with 226 million customers at April 2015). An Indian government committee in summer 2015 suggested that the locally based Airtel's zero-rated option should be permitted but foreign-controlled Facebook's Internet.Org prohibited. ${ }^{91}$ In response to concerns most vociferously raised in India but also in Brazil, the US, and other nations, Facebook made the terms of Internet.Org more transparent in May 2015, effectively opening access in principle to any app developer who could meet its terms. ${ }^{92}$ Nevertheless, Facebook's privacy policies continue to apply and it is not possible to use Internet.Org without also being a Facebook user, while Facebook accesses all your tracking behaviour while logged in to any partner sites and can share that with mobile IAPs.

87 World Bank, "World DataBank, Millennium Development Goals" (2015) available at http://databank.worldbank.org/data/reports.aspx?source=millennium-development-goals (accessed 5 Mar 16).

${ }^{88} \mathrm{P}$ Olsen, "This App Is Cashing in on Giving the World Free Data" (2015) available at http://www.forbes.com/sites/parmyolson/2015/07/29/jana-mobile-data-facebook-internet-org/ (accessed 9 Feb 16).

${ }^{89}$ Telecom Regulatory Authority of India, “Consultation Paper on Review of Internet Service” (2006) available http://www.trai.gov.in/WriteReaddata/ConsultationPaper/Document/consultation27dec06.pdf (accessed 5 Mar 16).

${ }^{90}$ Telecom Regulatory Authority of India, "Consultation Paper on Regulatory Framework for Overthe-top (OTT) services" (2015) available at http://trai.gov.in/WriteReaddata/ConsultationPaper/Document/OTT-CP-27032015.pdf (accessed 5 Mar 16).

91 Department of Telecommunications, "Committee Report Net Neutrality" (2015) available at http://dot.gov.in/sites/default/files/u10/Net_Neutrality_Committee report\%20(1).pdf (accessed 9 Feb 16).

92 Facebook, "Response to Free Basics Opponents, Item 6" (2015) available at https://info.internet.org/en/response-to-free-basics-opponents/ (accessed 9 Feb 16). 
Internet.Org's policies were carefully analysed by the Centre for Internet Studies in India. ${ }^{93}$ It was a matter of great priority for Facebook to expand its mobile network partnerships rapidly internationally, especially in India, in the face of a decline in youth MAUs in its home US market from 2013. The prize for FreeBasics was to grow subscribers in the Indian market more effectively. Zuckerberg stated:

[through] Internet.org in India now, there are already more than a million people who now have access to the internet who didn't otherwise [...] in terms of DAU (Daily Accessing User) growth, the three largest countries were India, the US and Brazil. ${ }^{94}$

The threat of regulatory action was expressed in July 2015 by the Joint Secretary of the Department of Telecommunications, V. Umashankar:

[I]f the need arises, the government and the regulator may step in to restore balance to ensure that the internet continues to remain an open and neutral platform for expression and innovation with no [IAP], or for that matter any content or application provider, having the potential or exercising the ability to determine user choice, distort consumer markets or significantly controlling preferences based on either market dominance or gatekeeping roles. ${ }^{95}$

He explained that the Telecoms Committee report delivered in July 2015 proposed ex ante regulation: "a licensee has to file the tariff plan with TRAI prior to the launch. TRAI would examine each such tariff filing carefully to see if it conforms to the principles of net neutrality and that it is not anti-competitive by distorting consumer markets." 96 Should zero-rating have already begun, as with Internet.org and Airtel, "penalties will be levied if there is a violation." 97

Facebook's partnership with third largest mobile operator Reliance Communications (RCom) to deliver Internet.Org was suspended on 24 December 2015 by Reliance, based on a request from the regulator TRAI. ${ }^{98}$ The sequence of events was apparently that RCom informed the regulator on 23 November that it offered Free Basics, to which the regulator replied on 21 December, and asked the carrier not to deploy

\footnotetext{
${ }^{93}$ R Jain, R Ravattu, R Dara and P Prakash, "Response to TRAI Consultation Paper on Regulatory Framework for Over-the-top (OTT) Services 27th March 2015" (2015) available at http://trai.gov.in/comments/24-April/Attachments-49/Response\%20- 
before submitting the terms and conditions, which includes tariff plans. This led Facebook CEO Zuckerberg to interrupt his paternity leave to write an extremely aggressive statement in a major Indian newspaper on 28 December, accusing critics of misrepresenting Facebook's plans. ${ }^{99}$ This backfired spectacularly, raising the spectre of economic colonialism which is a very emotive issue for India, even seventy years after independence from the UK. Guha and Aulakh explain that:

On December 9, Facebook started a mass campaign on its platform asking users to support Free Basics and urged them to email Trai declaring their support of 'digital equality.' Free Basics was sought to be conflated with digital equality, with Facebook pitching the product as a solution to connect the unconnected billions. [TRAI] had called Facebook's Save Free Basics campaign a 'crudely majoritarian and orchestrated opinion poll.' It also pulled up Facebook for the responses, which the regulator said didn't address any of the questions posed in the consultation paper. On January 1, Trai asked the company to alert its users to send revised responses to the questions on the consultation paper as a vote for Free Basics did not hold up as a valid response. ${ }^{100}$

The Prime Minister, who had been a supporter of Freebasics less than four months earlier, advised Facebook to behave less aggressively: "government must not allow any platform, no matter how popular, to monopolise any information system in the country as it can have far-reaching social, political and economic ramifications."101 This was the clearest indication of political pressure on the regulator to find against Facebook, which it did four days later.

The resulting regulations ban zero rating by both Freebasics via its Indian partner mobile network RCom, and domestic network Airtel's own zero rated offer. Those offers that subscribers have already received are permitted to continue for six months (to August-September 2016), but any breach of that or zero rated ("differential pricing" in the Regulations) offer to new subscribers would make the licensed network operator liable to 50,000 Indian Rupee daily fines (about \$700-750 USD). Licensing is permitted and controlled by the Indian Telegraphy Act 1885. Though these fines are low, the context of the regulator's power over other licence conditions makes it unlikely that a network operator would not comply.

India's road to a zero rating ban has been unusual: the regulator in spring 2015, and Prime Minister in September 2016, appeared minded to support differential pricing, but the strength of public opinion and lobbying directed by civil society coalition

\footnotetext{
${ }^{99}$ M Zuckerberg, "Free Basics Protects Net Neutrality: To Connect a Billion People, India must Choose Facts Over Fiction" (2015) available at http://blogs.timesofindia.indiatimes.com/toi-editpage/free-basics-protects-net-neutrality/ (accessed 9 Feb 16).

${ }^{100}$ R Guha and G Aulakh, "Trai bars Facebook Free Basics, Airtel Zero; releases notification on differential data pricing" (2016) available at http://telecom.economictimes.indiatimes.com/news/traibars-differential-pricing-of-data-services/50899934 (accessed 9 Feb 16).

${ }^{101}$ AS Mankotia, "PMO Displeased with Facebook's Reaction to Trai's Consultation Paper” (2016) available at http://articles.economictimes.indiatimes.com/2016-02-04/news/70343830_1_netneutrality-consultation-paper-digital-india (accessed 9 Feb 16).
} 
SaveTheInternet.in, compounded by Facebook's culturally insensitive aggressive lobbying, led to a complete reverse within months. ${ }^{102}$ Whether that decision leads other (post-colonial or otherwise) regulators into similar bans remains to be seen.

\subsection{Canada}

Canada has had a chequered record on net neutrality until 2015, with rules proclaimed by the regulator in 2009 but not enforced until this year. In 2011, the regulator explicitly supported capacity-based billing (rate caps) in Telecom Regulatory Policy CRTC 2011-703, Billing practices for wholesale residential high-speed access services (TRP 2011-703), which led the main ISPs to stop throttling video and other high bandwidth content as they had admitted so doing since 2008. It then adopted greater enforcement practices for net neutrality in 2014.

In 2008, the dominant incumbent Bell Canada was not ordered to stop throttling smaller ISPs to whom it provided wholesale connectivity, the CRTC instead launching a wider inquiry into Internet Traffic Management Practices ("ITMP" was the acronym used). ${ }^{103}$ In October 2009, Canada's regulator, the CRTC, announced that it would in future examine infringements of net neutrality, on a case-by-case basis, ${ }^{104}$ using existing powers under Section 36 of the Telecommunications Act 1993 which states "Except where the Commission approves otherwise, a Canadian carrier shall not control the content or influence the meaning or purpose of telecommunications carried by it for the public." 105 Thus the regulator chose not to act on any individual complaints until 2011. Geist in 2011 then documented failures to investigate, let alone act. ${ }^{106}$ A much-heralded 2011 ruling on ITMP and data management caps was little enforced. ${ }^{107}$ Until 2013, Canada's regulator claimed the power to regulate net neutrality, but chose to forebear, claiming no evidence of

\footnotetext{
102 A Srivas, "What Facebook's Spat with TRAI Tells Us About the Ethics of Digital Lobbying” (2016) available at http://thewire.in/2016/01/15/what-facebooks-spat-with-trai-tells-us-about-the-ethics-ofdigital-lobbying-19316/ (accessed 9 Feb 16).

${ }^{103}$ CRTC 2008-108, “Telecom Decision: The Canadian Association of Internet Providers' application regarding Bell Canada's traffic shaping of its wholesale Gateway Access Service Reference: 8622C51-200805153" (2008) available at http://www.crtc.gc.ca/eng/archive/2008/dt2008-108.htm (accessed 9 Feb 16).

${ }^{104}$ CRTC 2009-657, “Telecom Regulatory Policy: Review of the Internet traffic management practices of Internet service providers File number: 8646-C12-200815400" (2009) available at http://www.crtc.gc.ca/eng/archive/2009/2009-657.htm (accessed 9 Feb 16).

105 Telecommunications Act S.C. 1993, c. 38 Assented to 1993-06-23 (1993) available at http://lawslois.justice.gc.ca/eng/acts/T-3.4/page-1.html (accessed 9 Feb 16). This replaced the Railways Act 1906, which had been adapted to apply to all federal communications networks.

106 M Geist, “Canada's Net Neutrality Enforcement Failure” (2011) available at http://www.michaelgeist.ca/2011/07/net-neutrality-enforcement-fail/ (accessed 9 Feb 16).

107 (TRP 2011-703) Telecom Regulatory Policy CRTC 2011-703: Billing practices for wholesale residential high-speed access services, leading to abandonment of explicit P2P traffic throttling (2011) available at: http://www.scribd.com/doc/76105324/111219-The-Comp-Withdrawal-of-ITMP-Letter (accessed 9 Feb 16).
} 
problems that would justify action by the regulator, ${ }^{108}$ Even in mid-2015, research by Geist reveals that the CRTC emphasises transparency over fining miscreants where ISPs are shown to have misled consumers over net neutrality violations. ${ }^{109}$ The main form of Canada's net neutrality rules is not the ITMP decision itself, but rather provisions in the Telecommunications Act that pre-date the Internet (section 27(2) (no unjust discrimination) and section 36 (no interference with content). ${ }^{110}$

Jean-Pierre Blais became Chair of the CRTC in 2012 on the standard five-year term, announcing his arrival with the intention to properly regulate the sector in which the regulator "has reputational baggage, I want to build it back up." "This was in contrast with his laissez-faire business-friendly predecessors who "would rubberstamp almost anything they [corporates] proposed," 112 including the net neutrality issue. In his first year, Blaise carried out four major interventions: rejected former incumbent Bell Canada's initial takeover of Astral Media, until conditions were imposed that later revised and approved the merger; limited mobile phone contract durations to two years; pressured mobile ISPs into halved international roaming fees with the United States; investigated unbundling television channels leading to a decision to force unbundling in March 2015. Bell Canada's President was also rebuked officially by the CRTC for trying to interfere in editorial decisions to ban its TV station's coverage of the CRTC, with Blais stating: "An informed citizenry cannot be sacrificed for a company's commercial interests... corporate interests may have been placed ahead of fair and balanced news reporting." 113 The President of Bell Canada was immediately replaced on 9 April 2015.

Note that Bell has cross-media ownership of CTV, Canada's most popular TV channel, and until 2005 also owned the largest circulation newspaper, the Globe and Mail. The Bell Canada attempt to purchase Astral Media (owner of TV channels HBO Canada and The Movie Network) was announced in March 2012, but regulatory clearance only given when the majority of English-language programmnig was divested, alongside local programming and unbundling requirements which would

${ }^{108}$ J Miller, "Net-Neutrality Regulation In Canada: Assessing the CRTC's Statutory Competency To Regulate The Internet" (2012) available at http://journals.uvic.ca/index.php/appeal/article/viewFile/11888/3372 (accessed 9 Feb 16).

${ }^{109}$ M Geist, "Why Canada's Net Neutrality Enforcement is Going at Half-Throttle" (2015) available at http://www.michaelgeist.ca/2015/08/why-canadas-net-neutrality-enforcement-is-going-at-half-throttle/ (accessed 9 Feb 16).

110 C McTaggart, "Net Neutrality and Canada's Telecommunications Act" (2008), available at http://dx.doi.org/10.2139/ssrn.1127203 (accessed 9 Feb 16).

${ }^{111}$ CRTC, "Statement from Jean-Pierre Blais, Chairman of the CRTC, on monetary penalties and paper bill fees" (2014) available at http://news.gc.ca/web/article-en.do?nid=915129 (accessed 6 Mar 16) (In response to Bill C-43, the Economic Action Plan Act, No. 2, "the CRTC can now issue monetary penalties to any company or person that violates the Telecommunications Act as well as related CRTC decisions or regulations.”).

${ }^{112}$ S Ladurantaye, “The CRTC's Jean-Pierre Blais: The Regulator Who Speaks Truth to Power” (2013) available at http://www.theglobeandmail.com/report-on-business/careers/careers-leadership/the-crtcsjean-pierre-blais-speaking-truth-to-power/article15224721/?page=2 (accessed 6 Mar 16).

113 A Sharp, "BCE media executive apologizes for editorial intrusion" (2015) available at http://www.reuters.com/article/2015/03/25/us-canada-broadcasting-regulatoridUSKBNOML2JN20150325 (accessed 9 Feb 16). 
dilute any perceived threat to the public interest posed by dominance of Bell's programming in English-speaking Canada (note that Quebec, which has a quarter of Canada's population, is officially francophone, with only $7.7 \%$ anglophones, the latter of whom are mainly concentrated around the city of Montreal ${ }^{114}$ ).

Zero rating is not common practice, and has not been definitively banned. A new CRTC case may lead to a definitive ruling: the Videotron "Unlimited Music" case. ${ }^{115}$ The net neutrality regulatory battle in Canada played out as a broadcasting ownership battle, in which programme unbundling had as an integral part the decision to regulate zero rating in 2015 . It was to be expected that net neutrality violations favouring the company's preferred content would also form part of broadcasting regulation, specifically oversight of channel diversity. Unbundling of TV channels would not be appropriate alongside increased bundling of Internet distributed channels. The CRTC ruled in February 2015 that Bell had been "unlawfully" setting a double standard by exempting its \$5-a-month Bell Mobile TV app from download limits it places on subscribers to its mobile network, giving it until 25 April to correct its pricing. ${ }^{116}$ It also ruled against Quebec rival Videotron. Both are required to change to per gigabyte pricing. Bell had argued that the Mobile TV service provides forty-three channels, only twelve of which are owned by Bell, the remainder owned by other Canadian channel operators. The action was based on a 22 November 2013 complaint by student Ben Klass, supported by Telus, who argued that Bell in effect was marking up prices for competing streaming services by as much as $800 \% .^{117}$

On losing the action in 2015, Bell immediately filed a lawsuit in the Federal Court of Appeal whose hearing is pending, arguing that the CRTC was wrong to issue its decision under the authority of the Telecommunications Act, because Bell Mobile TV app is a broadcasting service, but it acts solely as an ISP for other parties' video. Broadcasting rules should therefore not apply, an argument approximating to that of the ISPs in the US, who claim Title II telecoms regulation should not apply to their ISP activities. Moreover, given that Mobile TV was providing Canadian content in competition to OTT player Netflix, the vast majority of whose content is from the United States, the Mobile TV decision may be portrayed as opposed to Canada's

114 See Wikipedia, "Language Demographics of Quebec" (2016) available at https://en.wikipedia.org/wiki/Language_demographics_of_Quebec\#Numbers_of native_speakers (accessed 9 Feb 16).

115 CRTC, "All Proceedings Open for Comment" (2015) available at https://services.crtc.gc.ca/pub/instances-proceedings/Default-

Defaut.aspx?S=O\&PA=T\&PT=A\&PST=A\&Lang=eng\& ga=1.72009299.1149531590.1442503569 (accessed 9 Feb 16). The two competing complaints filed by rival activists are items " 2 " and "4": In the Videotron case, the \#4 wireless carrier in one province (Quebec) is trying to increase music streaming usage by doing non-monetary deals with a wide variety of players (even Apple is reputed to be joining soon) and zero-rating streaming. Both complainants say that if Videotron sets a precedent, all other carriers will do so as well, but Guy Laurence, CEO of the largest carrier (Rogers), said they want to monetise data, not give it away.

${ }^{116}$ CBC News, "CRTC Backs Net Neutrality in Ruling Against Apps that Favour Certain Content" (2015) available at http://www.cbc.ca/news/business/crtc-backs-net-neutrality-in-ruling-against-appsthat-favour-certain-content-1.2936358 (accessed 6 Mar 16).

${ }^{117}$ K Stastna, "Bell's Discounting of Mobile TV Against the Rules, Complaint Claims" (2013) available at http://www.cbc.ca/news/technology/bell-s-discounting-of-mobile-tv-against-the-rulescomplaint-claims-1.2445059 (accessed 9 Feb 16). 
national content policies. It illustrates that not all zero pricing plans may be opposed on the same grounds and potential public interest at stake.

\subsection{United States}

The pre-history of United States regulation prior to the 2015 Open Internet Order is well-documented, with the 2010 Order $^{118}$ both highly controversial in its exclusion of mobile ("wireless") resulting in several data caps being imposed, notably by AT\&T in $2011,{ }^{119}$ zero ratings plans being adopted, and the Order itself becoming incapable of effective enforcement following a litigation which ended in $2014 .{ }^{120}$ Only lawyers may take joy that the FCC has spent a decade trying to enforce net neutrality since its original regulatory declaration. ${ }^{121}$

The 26 February 2015 Open Internet Order applies from 12 June 2015 and promised to enforce net neutrality. ${ }^{122}$ FCC claimed that the Order offered "Bright Line Rules":

- No Blocking: broadband providers may not block access to legal content, applications, services, or non-harmful devices.

- No Throttling: broadband providers may not impair or degrade lawful Internet traffic on the basis of content, applications, services, or non-harmful devices.

- No Paid Prioritization: broadband providers may not favor some lawful Internet traffic over other lawful traffic in exchange for consideration of any kind-in other words, no "fast lanes." This rule also bans ISPs from prioritizing content and services of their affiliates.

That final provision should eliminate zero-rating, but it does continue. Zero rating is a common practice in the US. For instance, T-Mobile offered thirty-three zero-rated music services in its Music Freedom Plan since $2014,{ }^{123}$ which has avoided any negative regulatory scrutiny in part due to the facts: its offer is non-exclusive, relates to music rather than heavily congesting and expensive video, and T-Mobile itself is the smallest of the national mobile ISPs. As Goldstein argues:

\footnotetext{
${ }^{118}$ FCC (2010) Report and Order Preserving the Open Internet, 25 FCC Rcd 17905.

${ }^{119}$ C Kang and H Tsukayama, “AT\&T to Throttle Data Speeds for Heaviest Wireless Users” (2011) available at http://www.washingtonpost.com/business/technology/atandt-to-throttle-data-speeds-forheaviest-wireless-users/2011/08/01/gIQAh0HBoI_story.html (accessed 6 Mar 16).
}

${ }^{120}$ Verizon v. Federal Communications Commission, 740 F.3d 623 (D.C. Cir. 2014); 11-1355, 14 January 2014.

121 FCC, "Internet Policy Statement 05-151" (2014) available at https://apps.fcc.gov/edocs_public/attachmatch/FCC-05-151A1.pdf (accessed 9 Feb 16). FCC, Madison River Communications, LLC, Order, DA 05-543, 20 FCC Rcd 4295 (2005).

${ }^{122}$ FCC, "Protecting and Promoting the Open Internet", GN Docket No. 14-28, Report and Order on Remand, Declaratory Ruling, and Order, FCC 15-24 (2015) available at https://apps.fcc.gov/edocs_public/attachmatch/FCC-15-24A1.pdf (accessed 9 Feb 16).

${ }^{123}$ L Northrup, "T-Mobile Now Exempts 33 Streaming Music Services From Data Limits, Adds Apple Music, Consumerist" (2015) available at http://consumerist.com/2015/07/28/t-mobile-now-exempts33-streaming-music-services-from-data-limits-adds-apple-music/ (accessed 9 Feb 16). 
Music Freedom plan is inclusive and supports numerous streaming music services, and since T-Mobile does not receive compensation from any company for not counting music streaming traffic against customers' data limits, such a plan is likely going to be fine by the FCC, since it benefits consumers. However, if a zero-rating plan were exclusive to one company that offers a particular type of service, that likely would draw more scrutiny from the FCC. ${ }^{124}$

As previously in the mergers of Bell Atlantic into Verizon and formation of AT\&T in 2005/6 and Comcast/NBC Universal in 2011, the US government has found itself most able to enforce net neutrality with decisions inserted into merger approvals. The merger of DirecTV into AT\&T imposed such conditions on zero rating. ${ }^{125}$ Comcast's attempted takeover of Time Warner Cable abandoned in 2015 would also have been likely to see such conditions imposed alongside interoperability/neutrality in its dealing with third party device authentication - which concerns the freedom to attach devices to the network. ${ }^{126}$ In its AT\&T/DirecTV approval of 27 July 2015, the FCC stated at Paragraph 395: "we require the combined entity to refrain from discriminatory usage-based allowance practices for its fixed broadband Internet access service." ${ }^{127}$ Moreover, in response to accusations that AT\&T ignored previous commitments in mergers, the FCC at Paragraph 398 "require that AT\&T retain both an internal company compliance officer and an independent, external compliance officer."

The FCC announced in July 2015 how to receive case-by-case advice about future plans, for instance zero rating schemes or Specialized Services, that may risk breaching net neutrality: "new process involves requesting and receiving an advisory opinion on specific, prospective business practices." 128 At paragraph 30-31 it explains that:

\footnotetext{
${ }^{124}$ P Goldstein, "Net Neutrality Rules won't Force Carriers to Get FCC Permission for New Plans" (2015) available at http://www.fiercewireless.com/story/net-neutrality-rules-wont-force-carriers-getfcc-permission-new-plans-offic/2015-02-26 (accessed 9 Feb 16).
}

125 Telecom Paper, "FCC Set to Approve AT\&T's DirecTV Takeover with Conditions" (2015) available at http://www.telecompaper.com/news/fcc-set-to-approve-atandts-directv-takeover-withconditions/ (accessed 9 Feb 16) ("If approved by the commissioners, 12.5 million customer locations will have access to a competitive fibre connection from AT\&T. The additional roll-out is around ten times the size of AT\&T's current FttP deployment and increases the national residential fibre build by over 40 percent... AT\&T will not be permitted to exclude affiliated video services and content from data caps on its fixed broadband connections. It will also be required to submit all competed interconnection agreements with the FCC.”)

${ }^{126}$ Brodkin, Jon, "Comcast to Stop Blocking HBO Go and Showtime on Roku Streaming Devices" (2014) Ars Technica, Condé Nast Digital, available at http://arstechnica.com/business/2014/12/comcast-to-stop-blocking-hbo-go-and-showtime-on-rokustreaming-devices/ (accessed 9 Feb 16).

${ }^{127}$ FCC, In the Matter of Applications of AT\&T Inc. and DIRECTV For Consent to Assign or Transfer Control of Licenses and Authorizations MB Docket No. 14-90 (2015) available at http://transition.fcc.gov/Daily_Releases/Daily_Business/2015/db0728/FCC-15-94A1.pdf (accessed 9 Feb 16).

${ }^{128}$ FCC, Open Internet Advisory Opinion Procedures, Protecting and Promoting the Open Internet, GN Docket No. 14-28 (2015) available at https://www.fcc.gov/document/public-notice-open-internetadvisory-opinions (accessed 9 Feb 16). 
Although advisory opinions are not binding on any party, a requesting party may rely on an opinion if the request fully and accurately contains all the material facts and representations necessary for the opinion and the situation conforms to the situation described in the request for opinion. ${ }^{129}$

Even though the FCC "may later rescind an advisory opinion, but any such rescission would apply only to future conduct and would not be retroactive." 130

\subsection{European Union}

In Europe, more complete confusion over zero rating and Specialized Services existed amongst governments, European institutions and regulators in 2016. European Parliament had negotiated a very "net neutrality lite" (rules on blocking/throttling) in 2009 to be implemented via regulatory action and reporting from 2011 under the amended Electronic Communications package. ${ }^{131}$ It essentially permitted discrimination (under certain conditions) on speed and price for new network capacity, but insists that existing networks do not discriminate "backwards" - that is, do not reduce the existing levels of service or block content without clear and transparent notice to users, and demonstrable reasonableness of those actions. This had to be adopted by national parliaments in June 2011 - though many delayed.

An Open Internet Regulation was first proposed by the European Commission in May 2013, passed at First Amendment in the European Parliament with amendments that would ban both zero rating and tightly defined Specialized Services as physically and/or logically separate to the Internet in April 2014. ${ }^{132}$ It was then revised in the Council of Ministers to more closely resemble the original proposal, agreed in a highly contentious trialogue with the Commission and Parliamentary Committee Chair (a Spanish conservative) in June 2015. EC Vice-President Ansip claimed after the trialogue in June 2015:

Internet service providers cannot act as gatekeepers to decide what people can, or cannot, access. Equal treatment and non-discrimination of traffic will be set in law... Paid prioritisation will be banned, which means that a start-up's website cannot be slowed down to make way for a larger company prepared to pay extra to get such an advantage. ${ }^{133}$

However, that fails to clarify either zero rating or Specialized Services, to the anger of Netherlands and Slovenian parliamentarians who continue to fear their laws will be

\footnotetext{
${ }^{129}$ Ibid.

${ }^{130}$ Ibid.

${ }^{131}$ EU Directive 2009/136/EC, and the Declaration appended to EU Directive 2009/140/EC.

${ }^{132}$ C Marsden, “Commissioner Kroes Can Skype her Grandchildren’s Mobiles in Retirement?” (2014) available at http://blogs.lse.ac.uk/mediapolicyproject/2014/04/04/will-commissioner-kroes-be-able-toskype-her-grandchildrens-mobiles-in-retirement/ (accessed 9 Feb 16).

${ }^{133}$ A Ansip, "Making the EU Work for People: Roaming and the Open Internet" (2015) available at https://ec.europa.eu/commission/2014-2019/ansip/blog/making-eu-work-people-roaming-and-openinternet en (accessed 9 Feb 16).
} 
undermined by the weaker European compromise Regulation adopted. It returned to the Parliament for a vote on potential amendments which failed, meaning the compromise Regulation becomes law in all twenty-eight Member States in April 2016. Regulation 2120/2015 which regulates for open Internet access (as in the US, not using the term "net neutrality") was passed by the European Parliament on 27 October 2015. ${ }^{134}$

Although many net neutrality elements have been included in the new Regulation, the lack of any explicit mention of the net neutrality principle is notable. Rather than unequivocally affirming the three pillars of net neutrality, i.e. no blocking, no throttling and no paid prioritisation, the EU policymakers enshrined only the first two components into the regulation, thus tempering neutrality into a less principled vague "open Internet." The good news for users is that Europeans have the:

right to access and distribute information and content, use and provide applications and services, and use terminal equipment of their choice, irrespective of the end - user's or provider's location or the location, origin or destination of the information, content, application or service, via their internet access service [Article 3 of the Regulation].

Associated with this right is the IAPs' obligation to "treat all traffic equally" with reasonable traffic management that should be "transparent, non-discriminatory and proportionate" and, very importantly, "shall not be based on commercial considerations but on objectively different technical quality of service requirements of specific categories of traffic." This is an important step forward for those Europeans that were lacking basic protections.

It is necessary to stitch together the interpretations of the European Commission issued at the time of the Regulation's approval in its MEMO-15-5275, ${ }^{135}$ with the clarifications and workplan of the European regulators working as BEREC. BEREC is charged with ensuring it issues guidelines by August 2016 for interpretation of the Regulation by NRAs:

The Telecoms Single Market Regulation includes a duty in Article 5(3) for BEREC to lay down guidelines for the implementation of the obligations of NRAs related to the supervision, enforcement and transparency measures for ensuring open Internet access. These guidelines should contribute to the consistent application of the Regulation, and be produced after consulting stakeholders and in close cooperation with the European Commission. ${ }^{136}$

\footnotetext{
${ }^{134}$ L Belli and C Marsden, "Not Neutrality but 'Open Internet' à l'Européenne” (2015) available at http://blogs.lse.ac.uk/mediapolicyproject/2015/10/29/not-neutrality-but-open-internet-a-la-europeenne/ (accessed 9 Feb 16).

${ }^{135}$ EU MEMO-15-5275, "Fact Sheet: Roaming Charges and Open Internet: Questions and Answers" (2015) available at http://europa.eu/rapid/press-release_MEMO-15-5275 en.htm (accessed 9 Feb 16).

${ }^{136}$ BoR "Statement on BEREC's work to produce guidelines for the implementation of net neutrality provisions of the TSM regulation" (2015) available at http://berec.europa.eu/eng/document_register/subject_matter/berec/press_releases/5588-statement-on-
} 
The deadlines are as follows:

- Entry into force of the Regulation took place on 30 November 2015; the entire Regulation is applicable 30 April 2016 except for certain provisions (mainly on roaming).

- The deadline for Member States to repeal national measures (including selfregulatory measures) which go against Article 3(2) or 3(3) is 31 December 2016, which must be notified to the Commission by 30 April 2016.

- Deadline for publishing BEREC's implementation guidelines under Recital 19 is 30 August 2016. European Commission's report to the European Parliament and the Council reviewing Article 3 (safeguarding of open internet access), Article 4 (transparency measures for ensuring open internet access), Article 5 (supervision and enforcement) and Article 6 (penalties), including proposals for amendments, if necessary, must be delivered by 30 April 2019.

- The Commission will have to issue a report every four years as of 30 April 2019. ${ }^{137}$

BEREC explained its outstanding concern on four topics: traffic management practices; Specialized Services; transparency in Internet access quality; and "commercial practices", such as zero-rating. In 2016 the co-chairs of the Net Neutrality Working Group (NNWG) - note that BEREC was happy to use the term net neutrality whereas the Regulation will not -were Ofcom for the UK and NKom for Norway (which had co-chaired the group since its foundation in 2011). Team leaders were Italy's AGCOM (traffic management practices); Belgium (Specialized Services); Greece (transparency in Internet access quality); and Ofcom for the UK ("commercial practices", such as zero-rating).

The Commission's Memo-15-5275 stated:

Zero rating, also called sponsored connectivity, is a commercial practice used by some providers of [Internet] access, especially mobile operators, not to count the data volume of particular applications or services against the user's limited monthly data volume. Commercial agreements and practices, including zero rating, must comply with the other provisions of the Regulation, in particular those on nondiscriminatory traffic management. Zero-rating could in some circumstances have harmful effects on competition or access to the market by new innovative services and lead to situations where endusers' choice is materially reduced in practice. ${ }^{138}$

The EC argues that:

\footnotetext{
berec-work-to-produce-guidelines-for-the-implementation-of-net-neutrality-provisions-of-the-tsmregulation (accessed 22 Mar 16).

${ }^{137}$ MF Pérez, "Net Neutrality: Document Pool II" (2015) available at https://edri.org/net-neutralitydocument-pool-2/ (accessed 9 Feb 16).

${ }^{138}$ EU MEMO-15-5275, note 124 above (emphasis added).
} 
The new rules therefore contain the necessary safeguards to ensure that providers of [Internet] access cannot circumvent the right of every European to access internet content of their choice, and the provisions on non-discriminatory traffic management, through commercial practices like zero-rating. ${ }^{139}$

Genna very strenuously disagrees with that interpretation:

This is completely false and misleading! [...] [The] power of national regulators will be materially weakened because of the ambiguous wording of $[\mathrm{A}] \mathrm{rticle} 3$ of the European regulation [...] read together with recital 7 (a recital, not a binding provision!) of the same regulation [...] . [It] is absolutely unclear if and to what extent national regulators can intervene in order to prohibit such discriminations. The Dutsch (sic) and Slovenian legislations were quite clear [...] such legislations will need to be repealed. ${ }^{140}$

I tend to agree with Genna, and the Dutch and Slovenian governments, that the EC interpretation is misleading, deliberate or not. Ofcom questions for BEREC were seeking views regarding different forms of data caps:

a) What is your understanding of the term "commercial practices" (Ref. Article 3(2))? Do you think there is a demand for "commercial practices" such as zero-rating, from the end users' point of view?

b) Article 3 (2) foresees contractual freedom and ISPs' freedom to conduct commercial practices. Could you provide examples when/under which circumstances commercial practices would limit the rights of end users? (Ref. Article 3(2) and recital 7)

c) What is your understanding or view regarding the monitoring of traffic for the purpose of traffic management (ref. Article 3(3) subpara 2)? What should ISPs be allowed to do in that regard under the TSM regulation? ${ }^{141}$

It appears from the questions that Ofcom has a much more permissive view of zero rating than the Commission's memo, which is unsurprising given the UK's long standing hostility to regulation of net neutrality. The lack of clarity in the Regulation means that BEREC guidelines in 2016 will be eagerly awaited on both zero rated

\footnotetext{
${ }^{139}$ Ibid (emphasis added).

${ }^{140}$ I Genna, "Zero-rating: The European Parliament Washing Hands like Pontius Pilate” (2015) available at https://radiobruxelleslibera.wordpress.com/2015/10/26/zero-rating-the-europeanparliament-washing-hands-like-pontius-pilate/ (accessed 6 Mar 16) (emphasis added).

${ }^{141}$ BoR, "Draft Agenda for the 25th meeting of the BEREC Board of Regulators in London UK (hosted by Ofcom" (2015) available at http://berec.europa.eu/eng/document_register/subject_matter/berec/board_of regulators_meetings/agen das/5510-draft-agenda-for-the-25th-meeting-of-the-berec-board-of-regulators-in-london-uk (accessed 22 Mar 2016).
} 
services, notably already regulated in Slovenia, Netherlands and Norway, and Specialized Services.

\section{Toolkit for Neutrality Regulation}

The case studies have provided a variety of responses to net neutrality violation in practice, with zero rating as the main concern in 2015. I now draw on those case studies to offer some elements that may be suited to a toolkit for regulators to respond to net neutrality concerns. It offers several elements:

- how to engage stakeholders, an especially important issue in the US, Brazilian and Indian case studies;

- how to measure neutrality, essential to the forthcoming BEREC Guidelines for the European Union and its member states;

- how to access prior knowledge in technical advice, which will help in defining the forensics of the regulation of zero rating and net neutrality more broadly; and

- an example of how regulators may respond to zero rating offers, short of the total prohibitions seen in Chile, India, Slovenia, Norway and Netherlands.

The toolkit is not prescriptive but descriptive, and points out that in regulating zero rating, as well as so-called Specialized Services, there remain serious research gaps in the analysis. These gaps were predictable five years ago ${ }^{142}$ but have only slowly been addressed, reflecting the political uncertainty of net neutrality regulation.

\subsection{Stakeholder Engagement}

As seen, no decision has been made in Brazil or the United Kingdom. All of the case studies implemented some type of regulation of zero rating, except Brazil where a consultation is ongoing, though in the United States and Chile, this appears to have exceptions (for music and video streaming with T-Mobile in the US, Wikipedia Zero in Chile). The nations with the fastest median Internet access, the Netherlands and Norway, also have the strictest net neutrality regulation in practice.

The use of multistakeholder forums to consult on policy was made, in addition to parliamentary discussion, in Norway, the United States, Brazil, India, and Canada. Digital participation resulted in four million replies in the US, two million in India, in favour of some form of neutrality. The Netherlands and Slovenia had extensive parliamentary debate about their net neutrality laws. This confirms that at least in form, the telecoms regulators remain best of breed in terms of making consultations widely available and receiving significant numbers of non-traditional responses.

\footnotetext{
${ }^{142}$ See C Marsden, Network Neutrality: Towards a Co-regulatory Solution, note 36 above, Chapter 8.
} 


\subsection{Measurement}

Research is needed to examine both enforcement of transparency in TMP by governments and their agencies, notably through use of SamKnows monitoring (Brazil, US, UK, EU, Canada) and the publication of key metrics, and enforcement by regulators following infringement actions where published.

Seven of the eight national case studies are now using measurement devices in the consumer's home. SamKnows is now active in measuring end-user TMPs in contracts with regulators in the US, Brazil, UK, Canada, and the European Union as a whole. ${ }^{143}$ This has supplanted self-reporting of violation by the ISPs, and network measurement by downloaded diagnostic tools, as the preferred method of discovering TMPs. Given the lack of clarity in the latter, and obvious incentive paradox in asking ISPs to selfreport violation, the approach appears the best fit.

The US regulator is taking action to actively consult on future TMPs that may violate neutrality, via its "advisory opinion" approach. Even critics of net neutrality acknowledge that better measurement of end-user experience is a vital contributor to forcing ISPs to offer increased transparency to end users. ${ }^{144} \mathrm{~A}$ report for Ofcom published in August 2015 concluded that an approach based on a quality floor (i.e. minimum service quality, possibly based on a new universal service standard) would help app designers and users understand better how SamKnows-type measurement can help them make better choices. ${ }^{145}$

The advanced measurement standards emerging may help regulators and consumers understand how best to enforce net neutrality standards.

\subsection{Technical Advice}

Technical elements of net neutrality remain complex in both resource and interpretation for regulators, especially those with fewer human resources and technical experience. It would be helpful if greater clarity on such future approaches were to build on the former role of the Advisory Committee of the FCC in 2011-12, and Broadband Internet Technical Advisory Group (BITAG, a US self-regulatory forum established after the 2010 Open Internet Order) in the period since. Between OIAC, BITAG and BEREC, many useful technical and policy reports have been produced since 2011 (Table 2).

\footnotetext{
143 See SamKnows, "Regulators" (2015) available at https://www.samknows.com/regulators, https://www.samknows.com/history (accessed 9 Feb 16).

144 M Geddes, "Ofcom Publishes Scientific Report on Net Neutrality" (2015) available at https://www.linkedin.com/pulse/ofcom-publishes-scientific-report-net-neutrality-martingeddes?trk=hp-feed-article-title-share (accessed 9 Feb 16).

${ }^{145}$ Predictable Network Solutions Limited, “A Study of Traffic Management Detection Methods \& Tools for Ofcom MC 316” (2015) available at http://t.co/rkVY62oRuf (accessed 9 Feb 16).
} 
Table 2. BEREC, BITAG and OIAC Technical Reports 2011-15.

\begin{tabular}{|c|c|c|}
\hline BEREC 2011-14 ${ }^{146}$ & BITAG 2011-15 ${ }^{147}$ & OIAC 2012-13 \\
\hline $\begin{array}{l}\text { BoR (14) } 117 \quad 25 \text { September } \\
2014 \text { Monitoring quality of } \\
\text { Internet access services in the } \\
\text { context of net neutrality BEREC } \\
\text { report }\end{array}$ & $\begin{array}{l}2014 \text { Interconnection and } \\
\text { Traffic Exchange on the Internet }\end{array}$ & $\begin{array}{l}\text { August 20, } 2013 \text { Economic } \\
\text { Impacts of Open Internet } \\
\text { Frameworks }\end{array}$ \\
\hline $\begin{array}{l}2012 \text { statement } \\
\text { observations about net neutrality } \\
\text { for ETNO's proposal to (ITU) } \\
\text { World Conference on } \\
\text { International } \\
\text { Telecommunications }\end{array}$ & $\begin{array}{l}2014 \text { VoIP Impairment, Failure, } \\
\text { and Restrictions }\end{array}$ & $\begin{array}{l}\text { August 20, } 2013 \text { Policy Issues } \\
\text { in Data Caps and Usage-Based } \\
\text { Pricing }\end{array}$ \\
\hline $\begin{array}{l}2012 \text { IP interconnection in the } \\
\text { context of NN }\end{array}$ & $\begin{array}{l}2013 \quad \text { Real-time } \\
\text { Management of } \\
\text { Congestion }\end{array}$ & $\begin{array}{l}\text { August 20, } 2013 \text { Mobile } \\
\text { Ecosystem: AT\&T FaceTime } \\
\text { Case Study; Openness in the } \\
\text { Mobile Broadband Ecosystem }\end{array}$ \\
\hline $\begin{array}{l}2012 \text { Competition issues in the } \\
\text { context of NN }\end{array}$ & Port Blocking 2013 & $\begin{array}{l}\text { August 20, } 2013 \text { Specialized } \\
\text { Services: Summary of Findings } \\
\text { and Conclusions }\end{array}$ \\
\hline $\begin{array}{l}2012 \text { Guidelines for Quality of } \\
\text { service in the scope of NN }\end{array}$ & SNMP DDoS Attacks 2013 & $\begin{array}{l}\text { August 20, } 2013 \text { Open Internet } \\
\text { Label Study }\end{array}$ \\
\hline $\begin{array}{l}2011 \text { - Framework for Quality of } \\
\text { service in the scope of NN }\end{array}$ & $\begin{array}{l}\text { Large Scale Network Address } \\
\text { Translation } 2012\end{array}$ & $\begin{array}{l}\text { January 17, } 2013 \text { Specialized } \\
\text { Services }\end{array}$ \\
\hline $\begin{array}{l}2011 \quad \text { Guidelines for } \\
\text { Transparency in the scope of NN }\end{array}$ & IPv6 DNS Whitelisting 2011 & $\begin{array}{l}\text { January 17, } 2013 \text { Economic } \\
\text { Impact Data Cap }\end{array}$ \\
\hline
\end{tabular}

\footnotetext{
${ }^{146}$ NKOM, "BEREC and Net Neutrality" (2013) available at http://eng.nkom.no/technical/internet/netneutrality/berec-and-net-neutrality (accessed 9 Feb 16). Note that the BEREC site lists several other draft papers: "BoR (13) 117 Ecosystem Dynamics and Demand Side Forces in Net Neutrality: Progress Report and Decision on Next Steps"; "BoR (12) 34 BEREC public consultations on Net Neutrality Explanatory paper"; "BoR (12) 31 Differentiation practices and related competition issues in the scope of Net Neutrality - Draft report for public consultation"; "BoR (12) 30 A view of traffic management and other practices resulting in restrictions to the open Internet in Europe - Findings from BEREC's and the European Commission's joint investigation"; "BoR (12) 32 BEREC Guidelines for Quality of Service in the scope of Net Neutrality- Draft for public consultation"; "BoR (12) 33 An assessment of IP-interconnection in the context of Net Neutrality - Draft report for public consultation"; "BoR (11) 67 Guidelines on transparency as a tool to achieve net neutrality"; "BoR (11) 44 Draft BEREC Guidelines on Net Neutrality and Transparency"; "BoR (10) 42 BEREC Response to the European Commission's consultation on the open Internet and net neutrality in Europe."

147 "BITAG: Broadband Internet Advisory Group" (2016) available at http://www.bitag.org/ (accessed 9 Feb 16).

148 “Open Internet Advisory Committee" (2015) available at https://www.fcc.gov/encyclopedia/openinternet-advisory-committee (accessed 9 Feb 16).
} 
These reports were all either written by a co-regulatory group, as with OIAC and BITAG (though the latter claims to be formally self-regulatory), or consulted with many stakeholders.

BEREC consulted very widely on its approach within the various regional regulator groups, including in what might be termed the "regulators' regulators" forum in Barcelona on 2-3 July 2015, when no less than ten national regulators explained their approaches to net neutrality. BEREC met with EaPeReg (Eastern Partnership Electronic Communications Regulators Network), REGULATEL (Latin American Forum of Telecommunications Regulators) and EMERG (Euro-Mediterranean Regulators Group) for the high level Regulator Summit, representing over seventy regulators. ${ }^{149}$

In terms of the value of net neutrality to consumers, regulators in the Netherlands, UK, and BEREC, ${ }^{150}$ all commissioned specialist reports to use focus groups to ascertain consumer ignorance and anger. These are in addition to the SamKnows reports generally released on an annual basis by regulators.

\subsection{How to Regulate Zero Rating}

The issue of zero rating is highly contentious - a "bad case" on which to make net neutrality law as van Eijk describes it. I suggest two regulatory actions to encourage the correct use of zero rating:

1. treating zero rating as a short term exception to net neutrality, and

2. ensuring any such short term exception is not exclusive, by subjecting such contracts to "Fair, Reasonable and Non-Discriminatory" (FRAND) conditions. ${ }^{151}$

These conditions are not dissimilar to the principles by which the Wikimedia Foundation permits Wikipedia Zero to be offered by mobile ISPs, in that it:

allows other public interest websites to ride onto its own scheme, eschews any exclusive rights or exchange of payment between itself and mobile carriers, and forbids carriers from selling the service as part of a limited bundle. ${ }^{152}$

\footnotetext{
${ }^{149}$ BEREC, "Outcomes of the BEREC - EMERG - EAPEREG - REGULATEL SUMMIT, 2-3 July 2015" (2015) available at http://berec.europa.eu/eng/news and_publications/whats_new/3184outcomes-of-the-berec-emerg-eapereg-regulatel-summit-2-3-july-2015 (accessed 6 Mar 16).

${ }^{150}$ BoR (15) 90 of 8 June 2015, "Report on How Consumers Value Net Neutrality" (2015) available at http://berec.europa.eu/eng/document_register/subject_matter/berec/press_releases/5052-berecpublishes-its-report-on-how-consumers-value-net-neutrality (accessed 9 Feb 16).

${ }^{151}$ See the extensive discussion in I Brown and C Marsden, Regulating Code: Good Governance and Better Regulation in the Information Age (Cambridge, MA: MIT Press, 2013).

152 N De Guzman, “Zero Rating: Enabling or Restricting Internet Access? Asia Pacific Bureau: Internet Society" (2014) available at http://www.internetsociety.org/blog/asia-pacific-bureau/2014/09/zerorating-enabling-or-restricting-internet-access (accessed 6 Mar 16).
} 
I consider exceptions, non-exclusivity and FRAND in turn.

Short term exceptions to net neutrality are likely given the post hoc nature of regulation: regulators lay out ground rules then respond to complaints regarding infringing practices. Difficult marginal cases can require extensive investigation. Such processes can take several months in the case of effective regulators, requiring both technical and economic analysis, a call for evidence, hearings and enforcement notices. In the case of litigious market actors, appeals against decisions can take months, years or longer to reach constitutional courts as final appeal court. There is nothing in zero rating to suggest it is anything but a straightforward case of discrimination, which should not be subject to such long appeal processes. As explained earlier, walled gardens are nothing new, represent obvious discrimination and have been outlawed by those countries with effective net neutrality regulation. Any attempt to offer a time-limited zero rated offer as an introduction to mobile data use could be flagged as such and limited by regulation to perhaps three to six months. This would be subject to FRAND conditions and regulatory enforcement.

FRAND conditions could be applied to:

1. Mobile ISP contracts with Free Basics and other affiliated content providers, including the ISPs' own subsidiaries, and

2. Conditions under which the content providers offer access to their own portals.

3. However, if zero rating is not taken up by a significant part of the subscriber base (e.g. $10 \%$ of each operator's users), there may be a case for a de minimis exception from FRAND/non-exclusivity. It would be difficult to argue in practice that such a small number on a short term basis distorts innovation significantly.

The first condition is relatively straightforward to implement in theory but difficult in practice, as it is basically vertical unbundling of the mobile ISP's business unit arrangements. One could also compare it to the regulatory treatment under EU antitrust law of competitors to Microsoft's applications interoperating with their dominant Windows operating system. ${ }^{153}$ However, not all regulators are capable of equal treatment of subsidiaries with competitors, especially in the resource-challenged developing world where independence and regulatory commitment are not as easily maintained.

An alternative form of FRAND may therefore be to regulate de facto at a regional or global level, in establishing the ground rules for access to the zero-rated platform which mobile ISPs will offer. In this case, the regulated actor is the "host" platform for those applications that will be offered. If applications to join such a platform offer - such as Free Basics or Wikipedia Zero's offer - are established under FRAND terms that can be examined and monitored independently, then the platform which is established for one developing market may, with few modifications, prove to be that offered in many others.

\footnotetext{
${ }^{153}$ K Coates, Competition Law and Regulation of Technology Markets (New York: OUP, 2011) at $245-$ 263.
} 
Mobile operators would like as much content delivered onto their networks as possible, including zero rated and directly peered Content Delivery Networks (CDNs such as Akamai or Level3). The appeal of Free Basics is the low bandwidth demand of its apps (no graphics, flash video). Some suggest directly peered CDNs should also be zero rated. It should be much cheaper (though not cost-free) to deliver content from a locally peered source. That should be passed on to the consumer, and zero rating is as good a way as any. Actual costs may be nearer zero than full price in any case. Note that without a data package alongside free content, content providers would be obliged to contract with a directly peered $\mathrm{CDN}$ - unless the zero rating offer is very short term (e.g. three months maximum) to let new users "taste" the edge of the Internet. I argue that FRAND and non-exclusivity should always be applied to zero rated offers, short term or long.

Jurisdiction will be the greatest challenge to any attempt to regulate the platform rather than the mobile ISP offering zero rating. There are three obvious routes to enforcement:

- via the telecoms regulator's enforcement of platform neutrality on the mobile ISP, and therefore into the contractual terms of its agreement with the platform;

- via antitrust as a merger condition for any platform that choses to expand into this area; or

- by a considered coordinated response by a network of net neutrality enforcement agencies at regional level, such as in BEREC.

The first has resource constraints except that the better resourced early mover regulators may establish ground rules that can be "copy and pasted" by later acting, less motivated regulators. The second is the type of net neutrality regulation that was adopted in the United States from 2005 onwards as an antitrust "default" rule against large ISPs that wished to merge. In the global view of such mergers, a net neutrality undertaking for a limited time period was considered by the merger partners to be a small price to pay. The third is also difficult in practice to implement, though larger well-resourced regulators (e.g. Germany/BEREC) advising their smaller cousins (e.g. Cyprus or Malta) can issue a decision or opinion that will help other regulators to take similar or identical action to enforce neutrality. Given the networks of regulators, consultants, civil society actors, academics and law firms that have exported and shared "best" ( sic) practice in telecom regulation since the first liberalisations in the 1980s (in Japan, US, Sweden and UK), such networks can be expected to actively engage in spreading such practices internationally. 


\section{Conclusion and Further Research Needs}

I considered whether zero rating poses a serious challenge to open Internet use, extensively examined in Part 3 the country case studies that demonstrate its regulation, and in Part 4, suggested areas for further independent research into the effectiveness of net neutrality regulation. I argued that zero rating is a relatively minor if highly controversial short term problem as compared to Specialized Services, not technologically but price determinist as I now explain.

The majority of "mobile" data traffic is actually downloaded to devices via Wi-Fi in home, office or hotspot locations. It is not the cost of mobile data plans that is the dominant price driver, but that of hardware and prevalence of Wi-Fi. There can never be as much Wi-Fi in developing countries as developed, but open Wi-Fi can be accessed relatively widely in countries where Internet policy is not dominated by the copyright maximalist lobby and morality (anti-pornography) cybercrime lobby. Hardware for mobile data is much cheaper than at its introduction a decade or more ago in the developed world, whether that be smartphones, laptops or tablets. ${ }^{154}$ Combining the huge advances in technology pricing/performance with the prevalence of Wi-Fi hotspots in 2015, it is clear that the environment for rapid adoption of mobile Internet access is far better than for fixed access in 2000. This applies despite the extremely high prices for mobile ISP data, which only forms a small part of the adoptive environment required to access the mobile Internet (arguably, no mobile ISP access is required at all given that schools, cafes, universities and other public areas offer free Wi-Fi). For example, only $43 \%$ of Brazilian smartphone users use data plans. $^{155}$

It is perhaps facile to argue that net neutrality regulation may be a somewhat blunt telecom regulatory instrument for a multi-faceted problem such as mobile Internet access, which also includes such policy issues as privacy and free expression as well as universal access and many Millenium Development Goals. David Kaye, United Nations' special rapporteur on freedom of expression, argues that:

In the longer term, net neutrality policies should be guaranteed wherever Internet infrastructure is being built out. The 13 'Necessary \& Proportionate' Principles, which apply human rights to communications surveillance, should also be adopted and implemented as a framework for rights-respecting connectivity. ${ }^{156}$

\footnotetext{
${ }^{154}$ N Freischlad, "Soon Everyone will be Able to Afford a Smartphone. But What about Data?" (2015) available at https://www.techinasia.com/smartphones-are-getting-cheaper-but-what-about-data/ (accessed 9 Feb 16). The article states: "Even in China, which is a more mature market [than Indonesia] by most measures and smartphone penetration is higher, data usage itself remains low. This tells us either Chinese smartphone users are not interested in using their phones on the go, or they are simply being thrifty."

155 P Olsen "This App Is Cashing In On Giving The World Free Data" (2015) available at http://www.forbes.com/sites/parmyolson/2015/07/29/jana-mobile-data-facebook-internet-org/ (accessed 9 Feb 16).

${ }^{156}$ D Kaye and B Solomon, "Merely Connecting the Developing World to the Internet Isn't Enough" (2015) available at
} 
He argued for a human rights-oriented connectivity programme to flow from the UN General Assembly debate on WSIS +10 and the newly updated Millennium Development Goals ("Global Goals for Sustainable Development" [GGSD] as adopted by the UNGA in September 2015) in December 2015. The GGSD emphasise that access to technology underpins every other "Global Goal" toward the eradication of extreme poverty. He particularly urged cautious adoption of the multinational platform pursued by Facebook, explaining that:

Mark Zuckerberg and Bono issued a call to 'unite the earth' and, with other global opinion shapers and business leaders, released a Connectivity Declaration to 'connect the world.' The U.S. State Department's Global Connect program makes Internet access a foreign aid priority... But connectivity alone cannot be global policy. Respect for privacy and the freedom of expression must go hand in glove with the drive to connection. ${ }^{157}$

He argued strongly that the Facebook-sponsored FreeBasics project, which offers free access to basic low-bandwidth versions of sponsored websites such as Facebook itself, Wikipedia and local news websites, offers a false equivalence with open Internet access, warning that government may "bless deals creating a two-tiered Internet pushed by so-called zero-rated service providers that limits browsing to preselected applications and establishes new gatekeepers" ${ }^{158}$ such as Facebook. This may be especially pernicious as FreeBasics is rolled out in least developed countries with very low fixed Internet access, and thus greater dependence on low bandwidth mobile connections. Examples are Zambia, Myanmar, Kenya, Peru and Guatemala.

Privacy remains a thorny issue, as well as being largely unregulated in developing countries. The wider issue of how Internet users of "free" apps such as Facebook and others are being monetised by advertisers is associated with the net neutrality and zero-rated debates, and in particular the correct policy responses. In countries such as Indonesia where monthly Average Revenue Per User (ARPU) is only $\$ 2.20$ for calls, texts and data, it is unsurprising that advertising is attractive as a further revenue partnership with zero rated apps. ${ }^{159}$ Freischlad considers:

Users of zero-rated apps should definitely be aware that aspects of their browsing, downloading, and searching behavior are likely being recorded and analyzed, as both the zero-rated app itself and the sponsor who footed the bill are interested in monetizing this data further. Is there no alternative to sponsored data? It's almost cynical: the most vulnerable people - low income communities just making their first

\footnotetext{
http://www.slate.com/blogs/future_tense/2015/10/13/the_u_n_wants_to_connect_the_world_to_the_int ernet_that_s_not_enough.html (accessed 9 Feb 16).

${ }^{157}$ Ibid.

${ }^{158}$ Ibid.

${ }^{159}$ Freischlad, note 147 above.
} 
steps on the internet - become easy targets of marketing messages and data mining. ${ }^{160}$

A much more popular service than Facebook (described as "privacy nightmares"161) is Jana Corporation's mCent, a service that lets users use mobile data as a reward if they try a new app - many of which are privacy invasive. The choice of trading your privacy for basic Internet access is a daily occurrence for the reported 30million mCent users. ${ }^{162}$

Privacy is an area of clear theoretical distinction between the EU and US, even though in practice smaller European states have highly inadequate regulators while the US has a strong federal regulator which has imposed fines on a scale far beyond its weakling European counterparts. The UK shares the US ambivalence towards privacy, its government campaigning in the last general election to leave the fortyseven member European Convention on Human Rights as a result of media-inspired fears of Article 8 privacy rights. ${ }^{163}$ In most developed countries, neutrality developed from privacy concerns, a dynamic which needs further empirical comparative research in the developing nation context.

Next to such a pervasive Internet policy problem vs privacy or free speech, is net neutrality an over-inflated sideshow, or a necessary precondition? Examination of national case studies helps to shed light on the extent to which net neutrality proves an essential pre-condition to solve other less technical, more politically accessible communications policy problems. More research is needed in this field as implementation of national and regional net neutrality legislation increases, but this introductory examination has shown that the roles of regulatory commitment, civil society activism and national political and market conditions are critical to the resolution of hard cases in net neutrality, specifically zero rating.

\footnotetext{
${ }^{160}$ Ibid.

${ }^{161}$ N Pahwa, "Facebook's Internet.org Platform is a Privacy Nightmare: Tracks Users on Partner Sites, Allows Telcos to Track" (2015) available at http://www.medianama.com/2015/05/223-facebooksinternet-org-privacy/ (accessed 9 Feb 16).

${ }^{162}$ Freischlad, note 147 above.

163 A Wagner, "The European Court of Human Rights Uncovered" (2015) available at http://ukhumanrightsblog.com/2015/08/14/the-european-court-of-human-rights-uncovered/ (accessed 9 Feb 16).
} 